\title{
Enhanced Artemin/GFR $\alpha 3$ Levels Regulate Mechanically Insensitive, Heat-Sensitive C-Fiber Recruitment after Axotomy and Regeneration
}

\author{
Michael P. Jankowski, Kristofer K. Rau, Deepak J. Soneji, Collene E. Anderson, and H. Richard Koerber \\ Department of Neurobiology, University of Pittsburgh School of Medicine, Pittsburgh, Pennsylvania 15261
}

We have shown recently that following saphenous nerve transection and successful regeneration, cutaneous polymodal nociceptors (CPMs) lacking transient receptor potential vanilloid 1 (TRPV1) are sensitized to heat stimuli and that mechanically insensitive, heatsensitive C-fibers (CHs) that contain TRPV1 increase in prevalence. Target-derived neurotrophic factor levels were also enhanced after axotomy and regeneration. In particular, the glial-cell line-derived neurotrophic factor (GDNF) family member artemin was found to be significantly enhanced in the hairy hindpaw skin and its receptor GDNF family receptor $\alpha 3$ (GFR $\alpha 3$ ) was increased in the L2/L3 dorsal root ganglia (DRGs) following nerve injury. In this study, we assessed the role of enhanced artemin/GFR $\alpha 3$ levels on the changes in mouse cutaneous $\mathrm{CH}$ neurons following saphenous nerve regeneration. We used a newly developed siRNA-mediated in vivo knockdown strategy to specifically inhibit the injury-induced expression of GFR $\alpha 3$ and coupled this with an ex vivo recording preparation to examine response characteristics and neurochemical phenotype of different types of functionally defined neurons after injury. We found that inhibition of GFR $\alpha 3$ did not affect the axotomy-induced decrease in CPM threshold, but transiently prevented the recruitment of $\mathrm{CH}$ neurons. Western blot and real-time PCR analysis of hairy hindpaw skin and L2/L3 DRGs after saphenous nerve regeneration suggested that inhibition of the potential initial injury-induced increase in enhanced target-derived artemin signaling resulted in dynamic changes in TRPV1 expression after regeneration. These changes in TRPV1 expression may underlie the functional alterations observed in $\mathrm{CH}$ neurons after nerve regeneration.

\section{Introduction}

Peripheral nerve regeneration and reinnervation of the target tissue has been shown to induce a variety of molecular and biophysical changes in sensory neurons due to changes in the target tissue and at the site of injury (Taniuchi et al., 1986; Terenghi, 1995; Smith and Skene, 1997; Ruocco et al., 2000; Campbell, 2001; Küry et al., 2001; Decosterd et al., 2002; Koerber and Woodbury, 2002; Priestley et al., 2002; Obata et al., 2003; Oaklander and Brown, 2004; Bennett et al., 2006; Koerber et al., 1999, 1994). These changes correlate with increased spontaneous activity (Xie et al., 1995; Djouhri et al., 2006), hyperexcitability (Wall and Devor, 1983; Kajander and Bennett, 1992; Amir et al., 1999; Waxman, 1999), and sensitization (Jankowski et al., 2009a), potentially leading to conditions of acute or chronic pain. We have shown that the peripheral response properties of two different populations of cutaneous C-fibers are significantly affected by axotomy and regeneration. Isolectin B4 (IB4)-binding, transient receptor potential vanilloid type 1 (TRPV1)-lacking, polymodal C-fibers (CPMs) have decreased thresholds to heat

Received April 26, 2010; revised Aug. 25, 2010; accepted Sept. 22, 2010

This work was supported by National Institutes of Health Grants NSO23725 and NS0532848 to H.R.K. and F32NS061487 to M.P.J. We also thank Weiwen Wang for technical assistance.

Correspondence should be addressed to Dr. H. Richard Koerber, Department of Neurobiology, University of Pittsburgh School of Medicine, 3500 Terrace Street, Pittsburgh, PA 15261. E-mail: rkoerber@pitt.edu.

DOI:10.1523/JNEUROSCI.2195-10.2010

Copyright $\odot 2010$ the authors $\quad 0270-6474 / 10 / 3016272-12 \$ 15.00 / 0$ stimuli, while IB4-negative, TRPV1-positive, mechanically insensitive, heat-sensitive C-fibers ( $\mathrm{CHs}$ ) increase in prevalence (Jankowski et al., 2009a).

It has been proposed that neurotrophic factors may play an important role in the injury-induced responses of peripheral sensory neurons (Lundborg et al., 1994; Wang et al., 2003). The glial-cell line-derived neurotrophic factor (GDNF) family is of interest because we have previously found that after axotomy, the cutaneous target is enriched in both GDNF and artemin (but not neurturin) along with a subsequent increase in their receptors in the dorsal root ganglia (DRGs) (Jankowski et al., 2009a). These ligands can signal through the ret tyrosine kinase receptor but bind to a glycosylphosphatidylinositol-linked coreceptor [GFR $\alpha 1-3$ (Sariola and Saarma, 2003)]. GDNF has the highest affinity for GFR $\alpha 1$, and artemin specifically binds GFR $\alpha 3$ (Baloh et al., 1998; Carmillo et al., 2005). GDNF is known to regulate the development of small-diameter nociceptors and may be involved in modulating mechanosensation (Albers et al., 2006). Artemin has been shown to be involved in nociceptor sensitization (Elitt et al., 2006), although others have suggested that artemin is antinociceptive (e.g., Gardell et al., 2003).

Since we found that TRPV1 was increased in the DRGs after reinnervation of the skin (Jankowski et al., 2009a), and that GFR $\alpha 3$ and TRPV 1 colocalize in murine $\mathrm{CH}$ fibers (Jankowski et al., 2009a), we hypothesized that enhanced target-derived artemin and DRG GFR $\alpha 3$ levels may be responsible for the induction of TRPV1 expression in the DRGs and the observed $\mathrm{CH}$ neuron 
recruitment after regeneration. Here, we tested this hypothesis by coupling our newly developed in vivo siRNA-mediated inhibition (Jankowski et al., 2009b) of injury-induced GFR $\alpha 3$ with functional recording of single afferents after saphenous nerve axotomy and regeneration using an ex vivo skin/nerve/DRG/spinal cord preparation. We then examined mRNA and protein levels of artemin in the skin and GFR $\alpha 3$ and TRPV1 in DRGs during and after regeneration to determine potential mechanisms.

\section{Materials and Methods}

Animals. Experiments were conducted using age-matched adult (4-6 weeks) male Swiss Webster mice (Hilltop Farms). All animals were housed in group cages, maintained in a $12 \mathrm{~h}$ light-dark cycle with a temperature-controlled environment, and given food and water ad libitum. All procedures used in these experiments were reviewed and approved by the Institutional Animal Care and Use Committee at the University of Pittsburgh. Animals were cared for and used in accordance with guidelines of the U.S. Public Health Service Policy on Humane Care and Use of Laboratory Animals and the NIH Guide for the Care and Use of Laboratory Animals and following institutional Association for Assessment and Accreditation of Laboratory Animal Care-approved practices.

Penetratin-1/siRNA linkage. siRNAs were conjugated to Penetratin-1 (MP Biomedicals) peptide as previously described (Davidson et al., 2004; Jankowski et al., 2006). Penetratin-1 peptide is a 16 aa peptide corresponding to the third helix of the homeodomain of Antennapedia protein that penetrates cell membranes (Derossi et al., 1998). siRNAs were synthesized with a $5^{\prime}$ thiol modification on the sense strand to allow Penetratin conjugation (Dharmacon). The nontargeting siRNA duplex also contained a 5' CY3 molecule conjugated to the antisense strand. Equimolar concentration of activated Penetratin-1, reconstituted in sterile water, was added to each of the siRNAs dissolved in $1 \times$ siRNA buffer (Dharmacon) and incubated for $15 \mathrm{~min}$ at $65^{\circ} \mathrm{C}$ and then $1 \mathrm{~h}$ at $37^{\circ} \mathrm{C}$. Stock siRNAs were brought to $400 \mathrm{nM} \mathrm{NaCl}$ to enhance solubility of Penetratin-linked siRNAs and kept at $-80^{\circ} \mathrm{C}$ until used.

Penetratin-1-modified siRNA injections. Mice were anesthetized by a mixture of ketamine and xylazine $(90 \mathrm{mg} / \mathrm{kg}$ and $10 \mathrm{mg} / \mathrm{kg}$, respectively). A small incision made in the midthigh region exposed the saphenous nerve to be injected. Pen-siRNAs were heated to $65^{\circ} \mathrm{C}$ for $5-15 \mathrm{~min}$ before injection. A $0.1-0.2 \mu \mathrm{l}$ quantity of $90 \mu \mathrm{M}$ Penetratin-1-linked control (PenCON) or GFR $\alpha 3$-targeting (Pen $\alpha 3)$ siRNAs was pressure injected at 10 psi into the saphenous nerve using a quartz microelectrode connected to a Picospritzer (Jankowski et al., 2009b). In each case, the electrode is positioned such that the injection is directed centrally toward the ganglion and away from the transection site. Under conditions in which mice received both nerve cut and siRNA injection, cuts were made 1-2 mm distal to the injection site without cleaning the surrounding area or damage to vasculature as described below. Tissues were collected at 7-84 d after nerve cut for analysis.

Saphenous nerve axotomy. Mice were anesthetized as described. A small incision was made in the skin at the midthigh level over the saphenous nerve. The exposed nerve was transected using fine iridectomy scissors without disturbing the surrounding connective tissue. Therefore, the cut ends of the nerve remained closely apposed. The wound was closed using 7.0 silk sutures. Animals were allowed to survive for 7-84 d after nerve injury for immunocytochemical, electrophysiological, Western blotting, and/or real-time PCR analysis.

Ex vivo preparation. The ex vivo somatosensory system preparation has been described in detail previously (Woodbury et al., 2001). Briefly, mice were anesthetized via injection of ketamine and xylazine (90 and 10 $\mathrm{mg} / \mathrm{kg}$, respectively) and perfused transcardially with oxygenated (95\% $\mathrm{O}_{2}-5 \% \mathrm{CO}_{2}$ ) artificial CSF (aCSF; in mM: $1.9 \mathrm{KCl}, 1.2 \mathrm{KH}_{2} \mathrm{PO}_{4}, 1.3$ $\mathrm{MgSO}_{4}, 2.4 \mathrm{CaCl}_{2}, 26.0 \mathrm{NaHCO}_{3}$, and 10.0 D-glucose) containing 253.9 $\mathrm{mm}$ sucrose at $12-15^{\circ} \mathrm{C}$. The spinal cord and the right hindlimb were excised and placed in a bath of aCSF. Hairy skin of the right hindpaw, saphenous nerve, DRGs, and spinal cord were isolated. Following dissection, the preparation was transferred to a separate recording chamber containing chilled oxygenated aCSF in which the sucrose was replaced with $127.0 \mathrm{~mm} \mathrm{NaCl}$. The skin was pinned out on a stainless steel grid located at the bath/air interface, such that the dermal surface remained perfused with the aCSF while the epidermis stayed dry. The platform served to provide stability during applied thermal and mechanical stimuli. The bath was then slowly warmed to $31^{\circ} \mathrm{C}$ before recording.

Recording and stimulation. All recordings were made from the L2-3 DRGs as these are the primary source of cutaneous fibers contained in the saphenous nerve. Sensory neuron somata were impaled with quartz microelectrodes (impedance $>150 \mathrm{M} \Omega$ ) containing $5 \%$ Neurobiotin (Vector Laboratories) in $1 \mathrm{~m}$ potassium acetate. Orthograde electrical search stimuli were delivered through a suction electrode on the nerve to locate sensory neuron somata innervating the skin. Peripheral receptive fields (RFs) were localized with a blunt glass stylus and von Frey hairs. When cells were driven by the nerve but had no mechanical RF, a thermal search was conducted. This was accomplished by applying hot $\left(\sim 52^{\circ} \mathrm{C}\right)$ and/or cold $\left(\sim 0^{\circ} \mathrm{C}\right)$ physiological saline to the skin. There was some concern that the brief but multiple applications of hot saline might cause sensitization of nociceptors during the course of an experiment. We examined this possibility in two recent studies (Lawson et al., 2008; Jankowski et al., 2009a) and found no change in average heat thresholds obtained at the onset of the experiment when compared to the average heat thresholds of the last fibers recorded. We have made a similar comparison of the data from these experiments in mice following nerve regeneration and also found no change in the average heat thresholds during the course of these experiments (data not shown).

The response characteristics of DRG cells were determined by applying digitally controlled mechanical and thermal stimuli. The mechanical stimulator consisted of a tension/length controller (Aurora Scientific) attached to a 1-mm-diameter plastic disc. Computer-controlled $5 \mathrm{~s}$ square waves of $1,5,10,25,50$, and $100 \mathrm{mN}$ were applied to the cell's RF. After mechanical stimulation, a controlled thermal stimulus was applied using a $3 \mathrm{~mm}^{2}$ contact area Peltier element (Yale University Machine Shop). The temperature stimulus consisted of a $12 \mathrm{~s} \mathrm{heat} \mathrm{ramp} \mathrm{from} 31$ to $52^{\circ} \mathrm{C}$ followed by a $5 \mathrm{~s}$ plateau at $52^{\circ}$. The stimulus then ramped back down to $31^{\circ} \mathrm{C}$ in $12 \mathrm{~s}$. Adequate recovery times $(\sim 30 \mathrm{~s})$ were used between stimulations. While recording from myelinated nociceptors in many cases, multiple heat applications were made, and in some cases the heat ramp was continued to $54^{\circ} \mathrm{C}$ and held for $5 \mathrm{~s}$. In other instances, fibers that were unable to be characterized by computer-controlled mechanical or thermal stimulation but were characterized by von Frey and/or saline stimuli were included for categorization of cell types but not included in the determination of thresholds and firing rates. All elicited responses were recorded digitally for offline analysis (Spike2 software, Cambridge Electronic Design). After physiological characterization, select cells were labeled by iontophoretic injection of Neurobiotin (2-3 cells per DRG). Peripheral conduction velocity was then calculated from spike latency and the distance between stimulating and recording electrodes (measured directly along the nerve). All electrophysiological and immunocytochemical experiments in naive and nerve-injured mice were performed blinded to the experimenter.

Tissue processing and analysis of recorded cells. Once a sensory neuron was characterized and intracellularly filled with Neurobiotin, the DRG containing the injected cell was removed and immersion fixed with $4 \%$ paraformaldehyde in $0.1 \mathrm{M}$ phosphate buffer $(\mathrm{PB})$ for $30 \mathrm{~min}$ at $4^{\circ} \mathrm{C}$. Ganglia were then embedded in $10 \%$ gelatin, postfixed in $4 \%$ paraformaldehyde, and cryoprotected in $20 \%$ sucrose. Frozen sections $(60 \mu \mathrm{m})$ were collected in PB and reacted with fluorescently tagged (FITC) avidin to label Neurobiotin-filled cells (Vector Laboratories). Next, each section was processed for IB4 binding (AlexaFluor 647; Invitrogen) and/or TRPV1 (1:500; Calbiochem), GFR $\alpha 3$ (1:100; R\&D Systems) immunohistochemistry. After incubation in primary antiserum, tissue was washed and incubated in Cy3- or Cy5-conjugated donkey anti-rabbit or donkey anti-goat secondary antisera (1:200; Jackson ImmunoResearch). Distribution of fluorescent staining was determined using Olympus FluoView 500 laser scanning confocal microscope (Olympus America). Sequential scanning was performed to prevent bleed-through of the different fluorophores.

Sections of hairy hindpaw skin from naive and nerve-injured mice were also dissected, fixed, and sectioned as described. Skin sections were blocked and incubated in primary antiserum rabbit anti-PGP9.5 (1:2000; 
Ultraclone) overnight at room temperature. After incubation in primary antiserum, tissue was washed and incubated in Cy3-conjugated goat anti-rabbit secondary antiserum (1:200; Jackson ImmunoResearch). Tissue was analyzed as described above using confocal microscopy.

The expression of GFR $\alpha 3$ was analyzed in three L3 DRGs from naive mice and three L3 DRGs from each nerve-injured group. The DRGs taken after electrophysiological experiments and were processed for immunohistochemical analysis as described above. The numbers of positive cells were determined as previously reported (Christianson et al., 2006; Jankowski et al., 2009a). In brief, three nonconsecutive sections were randomly chosen and $15 \mu \mathrm{m}$ stacks with $3-\mu \mathrm{m}$-thick optical sections were captured using a $40 \times$ oil-immersion objective. Multiple optical stacks were taken of each selected tissue section and visual confirmation was used to avoid analyzing cells twice. The number of GFR $\alpha 3$-positive cells were counted and averaged in the top and bottom optical section of each stack. The percentage of double-labeled cells was determined and reported as mean \pm SEM.

To determine the relative specificity of GFR $\alpha 3$, we also performed cell counts on naive tissue processed with IB4 to determine the overlap of these cell types. It is thought that GFR $\alpha 3$ and IB4 are relatively separate populations of sensory neurons in mouse DRGs using other GFR $\alpha 3$ antibodies (Orozco et al., 2001). IB4 also overlaps with GFR $\alpha 1$ and GFR $\alpha 2$ (Bennett et al., 1998), and it is known that IB4 and TRPV1 do not overlap extensively in mouse DRGs (Zwick et al., 2002). However, using our antibody, GFR $\alpha 3$-positive cells overlaps highly with TRPV1-expressing neurons (Elitt et al., 2006). Therefore our data confirm the notion that these two populations are mostly exclusive, as only $8.2 \pm 2.5 \%$ of GFR $\alpha 3$-positive cells in the DRGs bind IB4, suggesting that our antibody is specific.

RNA isolation and real-time PCR. Animals were anesthetized as described and the dorsal hindpaw skin was shaved. The skin innervated by the saphenous nerve was quickly removed, taking care to acquire skin from the central part of the innervation field. Trizol reagent was then used to isolate RNA from skin. The mice were then intracardially perfused with ice-cold $0.9 \%$ $\mathrm{NaCl}$ before dissection of DRGs. RNA isolation from the L2 and L3 DRGs was performed using Qiagen RNeasy mini kits for animal tissues using the supplied protocol. RNA concentrations were then determined by obtaining A260 readings on a GeneQuant spectrometer. Purified RNA was treated with DNase I (Invitrogen) for $15 \mathrm{~min}$ at room temperature, and $1 \mu \mathrm{g}$ of DNased RNA was reverse transcribed using Superscript II Reverse Transcriptase (Invitrogen). For real-time PCR, $20 \mathrm{ng}$ samples of cDNA were added to a SYBR Green MasterMix (Applied Biosystems) and run in triplicate on an Applied Biosystems Imager. Forward and reverse primer sequences used in real-time PCRs for GFR $\alpha 3$, TRPV1, ret, and GAPDH were obtained from Elitt et al. (2006). GFR $\alpha 1$, GFR $\alpha 2$, and P2X3 primer sequences were obtained from Jankowski et al. (2009a). IFN type I-induced and dsRNA-activated kinase (IFN type I) sequences are as follows: forward: $5^{\prime}-$ GTT AAA GAG CCC GCC GAA A-3'; reverse: 5' -TGG AAA AGC CAC TGA ATG TAG ATG$3^{\prime}$. Values were normalized to GAPDH and changes in expression are calculated as a $\Delta \Delta \mathrm{Ct}$ value that is determined by subtracting the cycle time $(\mathrm{Ct})$ values of the gene of interest from the GAPDH internal control for each sample
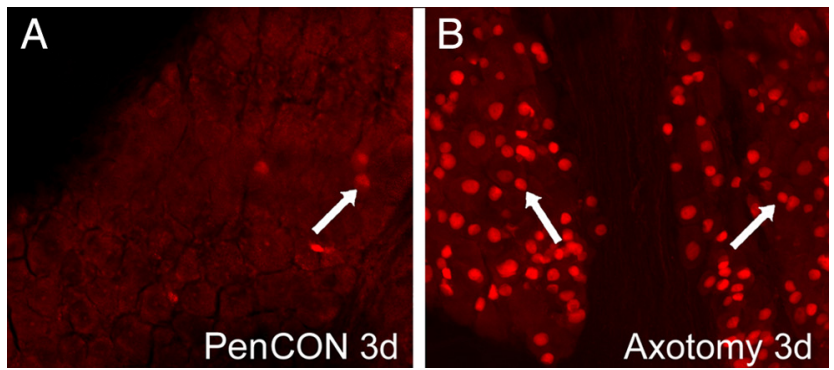

Figure 1. Light micrographs of $\mathrm{L} 3$ dorsal root ganglia immunolabeled for ATF3 after injection of PenCON siRNAs into the saphenous nerve or axotomy. Injection of PenCON siRNAs into the saphenous nerve does not cause significant injury of saphenous afferents to the same degree as axotomy. Injection of siRNAs into the saphenous nerve occasionally induces ATF3 expression in a few DRGs neurons (arrow) $3 \mathrm{~d}$ after injection $(\boldsymbol{A})$. However, complete transection of the saphenous nerve induces ATF3 expression in most DRG neurons (arrows) $3 \mathrm{~d}$ after injury (B).
A

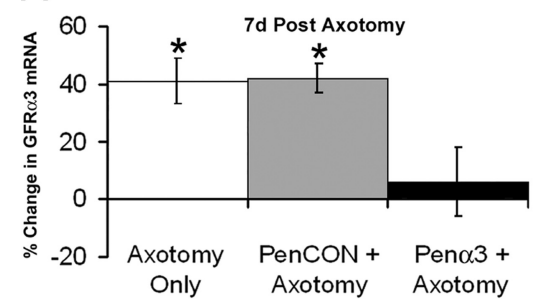

C

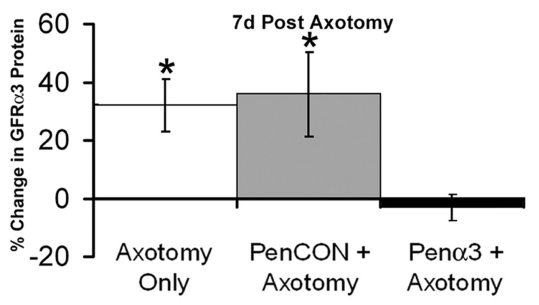

E

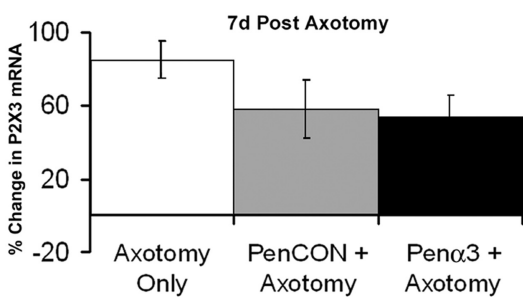

B

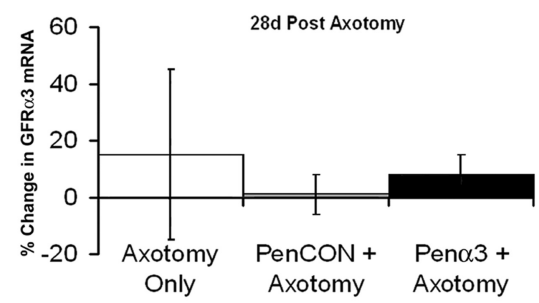

$\mathrm{D}$

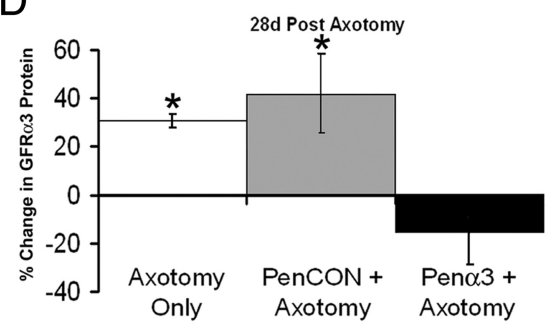

$\mathrm{F}$

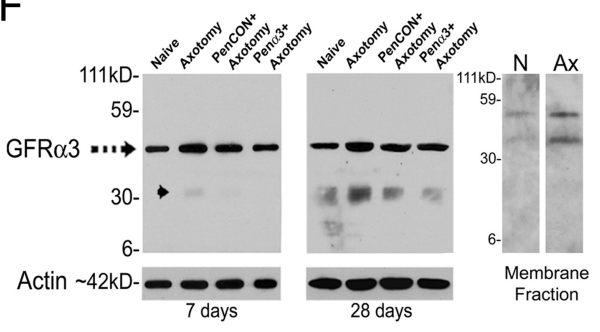

Figure 2. Real-time $P C R$ and Western blotting analysis of DRGs 7 and $28 \mathrm{~d}$ after saphenous nerve axotomy with or without injection of PenCON or Pen $\alpha 3$ siRNAs. GFR $\alpha 3$ mRNA is significantly increased in the L2/L3 DRGs $7 \mathrm{~d}$ after saphenous nerve axotomy alone $(41 \pm 8 \%$ ), and after axotomy plus PenCON injection ( $42 \pm 5 \%)$; however, injection of Pen $\alpha 3$ siRNAs prevented the axotomy-induced increase in GFR $\alpha 3$ mRNA ( $6 \pm 12 \%)$ at this time point $(\boldsymbol{A})$. mRNA levels of GFR $\alpha 3$ returned to baseline by $28 \mathrm{~d}$ after saphenous nerve axotomy under all conditions $(\boldsymbol{B})$. Western blot analysis verified that an increase in mRNA expression corresponded to an increase in protein expression $7 \mathrm{~d}$ after axotomy $(32 \pm 8 \%)$ and after PenCON siRNA injection plus axotomy (38 $\pm 14 \%)$, whereas injection of Pen $\alpha 3$ siRNAs plus axotomy $(-3 \pm 5 \%)$ displayed no increase in GFR $\alpha 3$ protein (C). Surprisingly, the initial increase in GFR $\alpha 3$ mRNA at $7 \mathrm{~d}$ induced a prolonged increase in GFR $\alpha 3$ protein at $28 \mathrm{~d}$ after axotomy (31 $\pm 3 \%$ ) and PenCON siRNA injection plus axotomy (42 $\pm 16 \%$ ). Injection of Pen $\alpha 3$ siRNAs plus axotomy did not show any rebound of GFR $\alpha 3$ protein $(-15 \pm 13 \%)$ at $28 \mathrm{~d}$ (D). Axotomyinduced expression of P2X3 ( $85 \pm 10 \%$ ) in the L2/L3 DRGs $7 \mathrm{~d}$ after saphenous nerve axotomy is not affected by injection of either PenCON $(58 \pm 16 \%)$ siRNAs or Pen $\alpha 3(54 \pm 12 \%)$ siRNAs (E). Representative Western blots are shown for GFR $\alpha 3$ protein normalized to actin at 7 and $28 \mathrm{~d}$ after saphenous nerve axotomy with or without injection of PenCON or Pen $\alpha 3$ siRNAs $(\boldsymbol{F})$. The mouse GFR $\alpha 3$ band is detected around $40 \mathrm{kDa}$ (dashed arrow) and a smaller product (arrowhead) is also detected around $30 \mathrm{kDa}$. ${ }^{*} p<0.05$. The membrane fraction of GFR $\alpha 3$ was also found to have enhanced levels in the DRGs $7 \mathrm{~d}$ after axotomy ( $\boldsymbol{F}$, inset; $\mathrm{N}$, naive; $\mathrm{Ax}$, axotomy). 

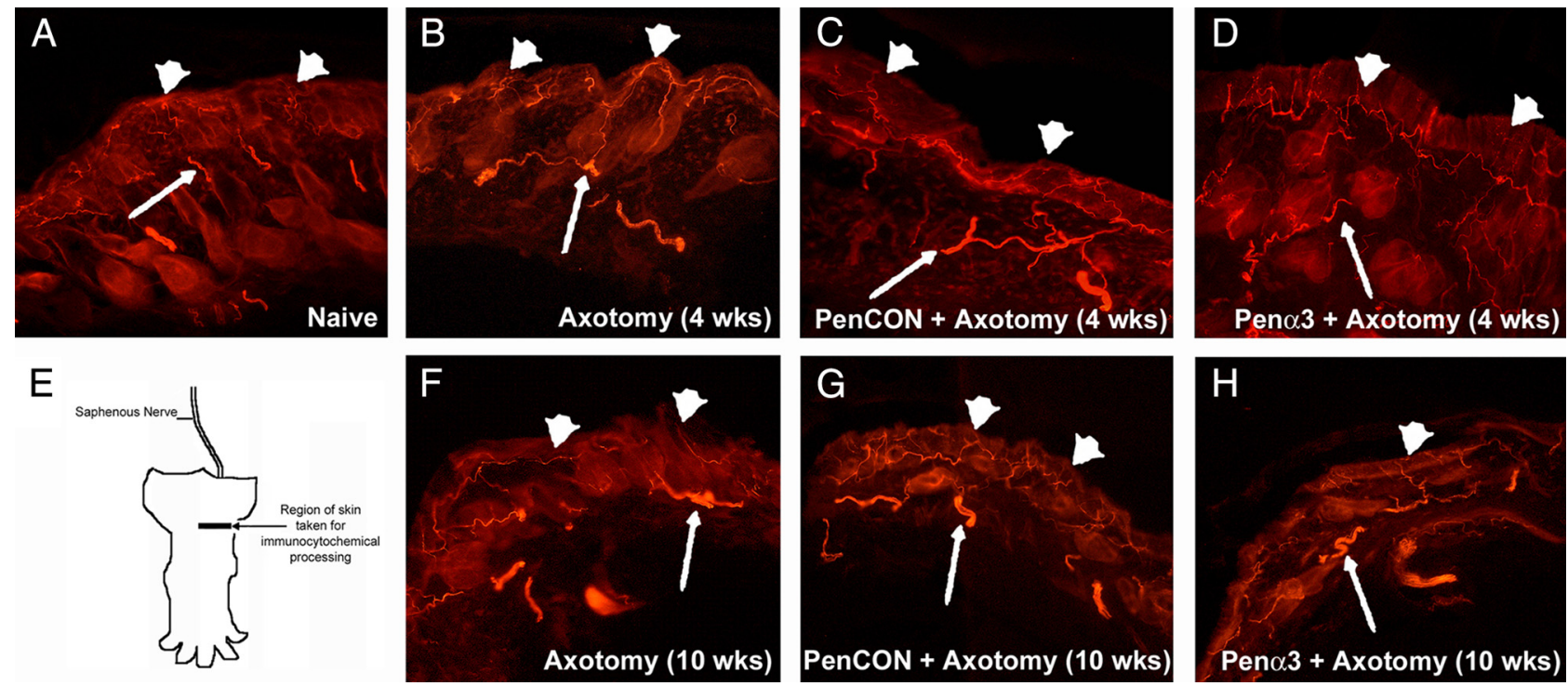

Figure 3. Light micrographs of saphenous nerve innervation area of the skin immunopositive for PGP9.5. Four weeks after axotomy of the saphenous nerve, the epidermis (arrowheads) and dermis (arrows) are readily reinnervated by regenerating saphenous afferents $(\boldsymbol{A}-\boldsymbol{C})$. Injection of control (B) or GFR $\alpha 3$-targeting siRNAs does not appear to effect the reinnervation of the skin. Similar results are found 10 weeks after axotomy under the three experimental conditions $(\boldsymbol{E}-\boldsymbol{G})$. The innervation pattern is not as extensive as uninjured control skin $(\boldsymbol{D})$ at 4 weeks, but appears normal by 10 weeks. A diagram of the area of hairy hindpaw skin taken for PGP9.5 immunocytochemistry is shown (H). Scale bar, $500 \mu m$.

and compared among samples. Fold change is described as $2^{\Delta \Delta \mathrm{Ct}}$ (Applied Biosystems), and twofold change equals $100 \%$ change. GAPDH did not change after axotomy in any samples relative to naive mice and verified the use of this internal control for normalization.

Western blot. Hairy hindpaw skin or DRGs from naive or nerveinjured mice was homogenized in lysis buffer containing $1 \%$ SDS, $10 \mathrm{~mm}$ Tris- $\mathrm{HCl}$, pH 7.4, and protease inhibitors $(1 \mu \mathrm{g} / \mathrm{ml}$ pepstatin, $1 \mu \mathrm{g} / \mathrm{ml}$ leupeptin, $1 \mu \mathrm{g} / \mathrm{ml}$ aprotinin, $1 \mathrm{~mm}$ sodium orthovanadate, and 100 $\mu \mathrm{g} / \mathrm{ml}$ phenylmethylsulfonyl fluoride; Sigma Biochemicals). Membrane fractions from pooled DRGs from either naive or nerve-injured mice were isolated with the Pierce membrane isolation kit according to the manufacturer's protocol. Total DRG samples $(10 \mu \mathrm{g})$ were centrifuged and boiled $10 \mathrm{~min}$ in a denaturing buffer containing $\beta$-mercaptoethanol and SDS before gel electrophoresis. Membrane fraction samples were heated to $37^{\circ} \mathrm{C}$ in the denaturing buffer containing $8 \mathrm{M}$ uric acid. Each sample was normalized for loading based on the volume of hydrophilic and hydrophobic fractions obtained according to the manufacturer's recommendations (Pierce). Samples were then separated on an $8 \%$ (artemin) or $10 \%$ (GFR $\alpha 3)$ SDS-polyacrylamide gel and transferred to a PVDF (Hybond) membrane (GE Healthcare) that was blocked in 5\% milk (in $0.1 \mathrm{M}$ Tris-buffered saline with $0.1 \%$ Tween 20 ) and then incubated with primary antibodies overnight at $4^{\circ} \mathrm{C}(\mathrm{GFR} \alpha 3$ : 1:100; R\&D Systems; artemin: 1:500; Santa Cruz Biotechnology; actin: 1:10,000; Sigma). Antibody binding was visualized using horseradish peroxidaseconjugated goat anti-rabbit or donkey anti-goat secondary antibodies $(1: 10,000)$ and chemiluminescent detection (Pierce Biochemical). Immunoreactive bands were analyzed by densitometry and intensity quantified using NIH ImageJ software. Band intensity was normalized to actin and reported as a percentage change.

Data analysis. One-way ANOVA tests and post hoc analysis (Tukey) were used to analyze differences in firing rate and instantaneous frequency along with mechanical and thermal thresholds of both A- and C-fibers. This information was sorted by neuronal functional type to examine whether or not certain classes of neurons have coherence with regard to the expression of any of the markers tested. Differences in fiber prevalence were determined by Fisher's exact analysis. Percentage changes in mRNA and protein were also determined to be statistically significant by ANOVA with post hoc analysis (Tukey). Statistical analyses were performed on the raw $\mathrm{Ct}$ data and represented for ease of presentation as a percentage change. Significance was set at $p<0.05$.

\section{Results}

In vivo inhibition of axotomy-induced GFR $\alpha 3$ expression

To test our hypothesis that enhanced target-derived artemin/ GFR $\alpha 3$ levels may be responsible for the induction of TRPV1 expression in the DRGs and the observed $\mathrm{CH}$ neuron recruitment after regeneration in vivo, we developed a technique that would allow us to specifically target injured cutaneous sensory neurons for mRNA inhibition and then test their response properties electrophysiologically. We have recently developed an in vivo siRNA-mediated knockdown strategy that allowed us to inhibit gene expression in vivo in neurons contained in an individual peripheral nerve (Jankowski et al., 2009b). Since this strategy for in vivo siRNA-mediated inhibition requires direct injection of the Penetratin-1 modified siRNAs, we wanted to first confirm that the injection itself was not causing significant injury. To test this, we performed immunocytochemical labeling of DRGs for activating transcription factor 3 (ATF3), a known marker of injured neurons (Tsujino et al., 2000). Three days after injection of nontargeting, control (PenCON) siRNAs into the saphenous nerve, few ATF3-positive neurons were found in the L3 DRG (L2-3 are the major source of afferent fibers in the saphenous nerve). At this same time point after complete transection of the saphenous nerve, numerous ATF3-positive neurons were found in the L3 DRG (Fig. 1), suggesting that minimal injury to afferents is occurring during these injections.

We next verified that changes in GFR $\alpha 3$ gene expression in the DRGs could be specifically inhibited by GFR $\alpha 3$-targeting (Pen $\alpha 3)$ siRNAs in saphenous neurons after axotomy. We analyzed changes in gene expression using real-time PCR and/or Western blot in the L2/L3 DRGs of mice 7 and $28 \mathrm{~d}$ following transection with or without injection of PenCON or Pen $\alpha 3$ siRNAs. Four naive mice and three to four axotomized mice per time point and condition were used for RT PCR and Western blot analyses. At $7 \mathrm{~d}$, GFR $\alpha 3$ mRNA was found to be significantly increased in the DRGs after axotomy alone (41 $\pm 8 \%)$ and after PenCON siRNA injection plus axotomy (42 $\pm 5 \%$ ) (Fig. $2 A)$. 

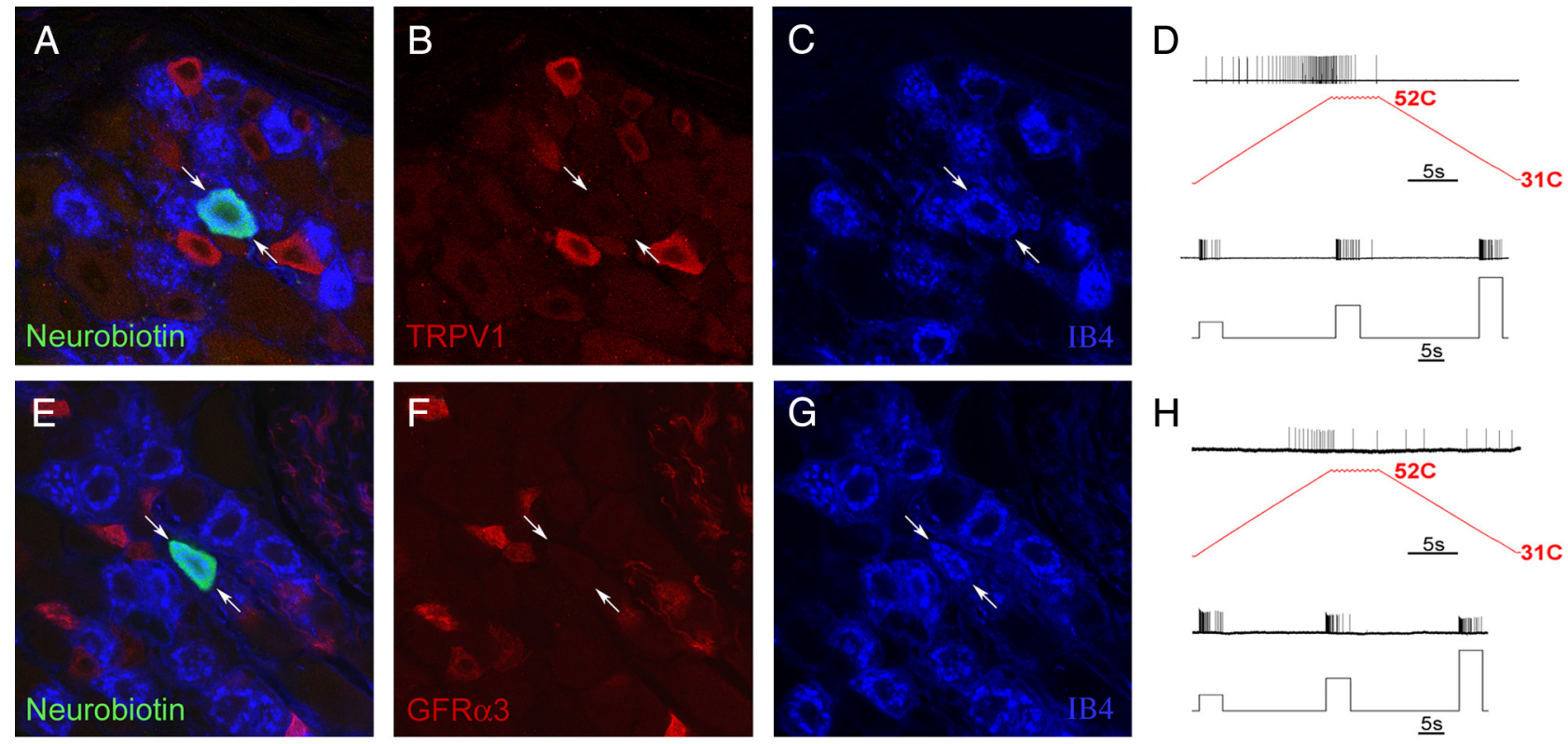

$\mathrm{H}$
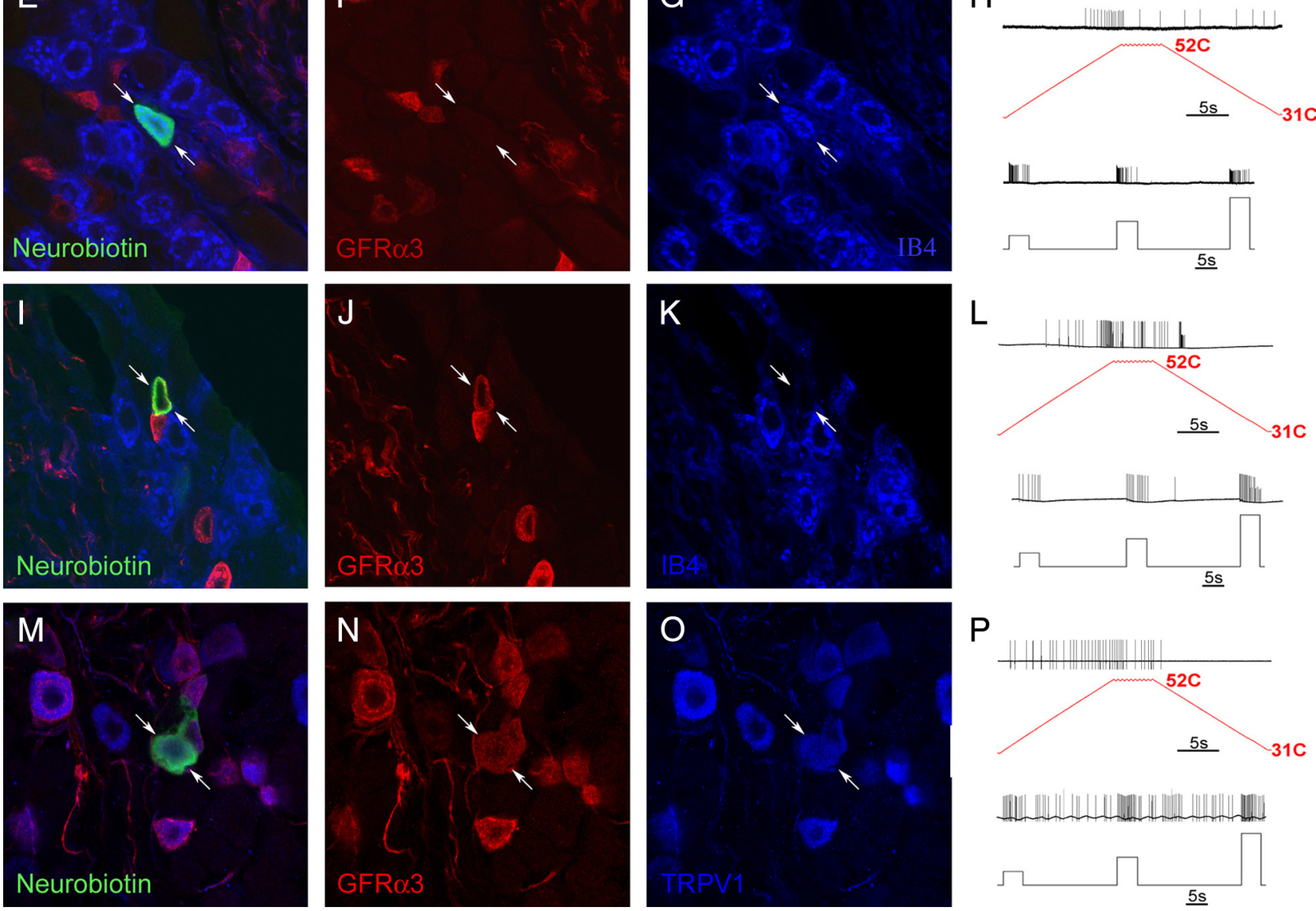

Figure 4. Characterization of the immunocytochemical and electrophysiological response properties of injured (PM fibers in the L2/L3 DRGs using the saphenous nerve ex vivo preparation. Examples of cutaneous sensory neurons intracellularly labeled with Neurobiotin ( $\boldsymbol{A}, \boldsymbol{E}$; arrows) found to be immunonegative for TRPV1 ( $\boldsymbol{B}$; arrows) and GFR $\alpha 3(\boldsymbol{F})$ but positive for IB4 (C, $\boldsymbol{G}$; arrows) responded to both mechanical and thermal stimulation $(\boldsymbol{D}, \boldsymbol{H})$, classifying them as (PMs. Examples of other cutaneous sensory neurons intracellularly labeled with Neurobiotin $(\boldsymbol{I}, \boldsymbol{M} ;$ arrows) responded to both mechanical and thermal stimulation $(\boldsymbol{L}, \boldsymbol{P})$, classifying them as (PM. In certain cases, Neurobiotin-labeled cells $(\boldsymbol{I}, \boldsymbol{M}$; arrows) that were found to be immunopositive for $G F R(\alpha 3)$; arrows) were negative for IB4 ( $\boldsymbol{K}$; arrows). CPM neurons found to be GFR $\alpha 3$ immunoreactive ( $\boldsymbol{N}$; arrows) were also occasionally found to be TRPV1 positive ( $\mathbf{0}$; arrows).

Pen $\alpha 3$ injection plus axotomy completely inhibited the injuryinduced increase in GFR $\alpha 3$ mRNA (Fig. 2A). Similar effects on protein expression were also found using Western blotting analysis (Fig. 2C,D,F) (axotomy: $32 \pm 8 \%$; PenCON plus axotomy: $38 \pm 14 \%$; Pen $\alpha 3$ plus axotomy: $-3 \pm 5 \%)$. Although the levels of GFR $\alpha 3$ mRNA returned to baseline by $28 \mathrm{~d}$ under all experimental conditions (Fig. 2B), GFR $\alpha 3$ protein levels remained elevated after axotomy $(31 \pm 3 \%)$ and following PenCON plus axotomy $(42 \pm 16 \%)$, while Pen $\alpha 3$ siRNA injection $(-15 \pm$ $13 \%$ ) dropped GFR $\alpha 3$ protein levels below baseline for at least 4 weeks after axotomy (Fig. 2D,F). To determine whether GFR $\alpha 3$ was also enhanced in the membrane, we performed Western blot analysis for GFR $\alpha 3$ on the membrane fractions of pooled DRGs from four mice $7 \mathrm{~d}$ after axotomy and compared them to pooled naive DRGs. We found GFR $\alpha 3$ to be enhanced in the membrane after injury (Fig. $2 \mathrm{~F}$, inset), thus further supporting the notion of potential enhanced artemin signaling after injury.

To confirm that GFR $\alpha 3$ inhibition was specific, we first analyzed the expression of P2X3 mRNA, which was also found to be increased in the DRGs $7 \mathrm{~d}$ after injury (Jankowski et al., 2009a). No change in P2X3 mRNA at $7 \mathrm{~d}$ (Fig. 2E) was detected under any condition. We then analyzed the expression of ret, GFR $\alpha 1$, and GFR $\alpha 2$ at 7 and $14 \mathrm{~d}$ after injury to verify that GFR $\alpha 3$ targeting siRNAs were not knocking down the expression of genes associated with other GDNF signaling pathways. We found no change in ret (axotomy: $6 \pm 6 \%$; PenCON plus axotomy: $18 \pm$ 7\%; Pen $\alpha 3$ plus axotomy: $1 \pm 6 \%$ ), GFR $\alpha 1$ (axotomy: $17 \pm 27 \%$; PenCON plus axotomy: $16 \pm 24 \%$; Pen $\alpha 3$ plus axotomy: $20 \pm$ 


\begin{tabular}{|c|c|c|c|c|c|}
\hline Condition & IB4+ & TRPV1+ & GFR $\alpha 3+$ & $\alpha 3+\& \mathrm{~V} 1+$ & $\alpha 3+\& \mathrm{IB} 4+$ \\
\hline \multicolumn{6}{|l|}{ CPM neurons } \\
\hline Axotomy & $12 / 12$ & $2 / 5$ & $2 / 15$ & $2 / 5$ & $0 / 10$ \\
\hline $\begin{array}{l}\text { PenCON + } \\
\text { axotomy }\end{array}$ & $11 / 14$ & $1 / 5$ & $3 / 15$ & $1 / 3$ & $1 / 12$ \\
\hline $\begin{array}{r}\text { Pen } \alpha 3+ \\
\text { axotomy }\end{array}$ & $10 / 15$ & $0 / 7$ & $2 / 16$ & $0 / 4$ & $0 / 12$ \\
\hline \multicolumn{6}{|l|}{ CH neurons } \\
\hline Axotomy & nt & $1 / 1$ & $1 / 1$ & $1 / 1$ & $\mathrm{nt}$ \\
\hline $\begin{array}{l}\text { PenCON + } \\
\text { axotomy }\end{array}$ & $0 / 3$ & $3 / 3$ & $6 / 6$ & $3 / 3$ & $0 / 3$ \\
\hline $\begin{array}{l}\text { Pen } \alpha 3+ \\
\text { axotomy }\end{array}$ & $\mathrm{nt}$ & $1 / 1$ & $1 / 1$ & $1 / 1$ & $\mathrm{nt}$ \\
\hline
\end{tabular}

nt, Not tested.

$21 \%$ ) or GFR $\alpha 2$ (axotomy: $-29 \pm 20 \%$; PenCON plus axotomy: $-40 \pm 21 \%$; Pen $\alpha 3$ plus axotomy: $-38 \pm 20 \%$ ) at $7 \mathrm{~d}$, nor was there an effect on the injury-induced changes in these receptors at $14 \mathrm{~d}$ after inhibition of GFR $\alpha 3$ (ret, axotomy: $1 \pm 5 \%$; PenCON plus axotomy: $-6 \pm 5 \%$; Pen $\alpha 3$ plus axotomy: $6 \pm 4 \%$; GFR $\alpha 1$, axotomy: $53 \pm 16 \%$; PenCON plus axotomy: $44 \pm 11 \%$; Pen $\alpha 3$ plus axotomy: $62 \pm 22 \%$; GFR $\alpha 2$, axotomy: $-31 \pm 20 \%$; PenCON plus axotomy: $-54 \pm 21 \%$; Pen $\alpha 3$ plus axotomy: $-64 \pm$ $21 \%$ ). There was also no rebound in GFR $\alpha 3$ mRNA at $14 \mathrm{~d}$ after knockdown (data not shown). We then wanted to confirm that there were no antiviral-related off-target effects of our siRNA injections. We therefore tested for IFN type I-induced and double-stranded RNA-activated kinase (IFN type I). This gene was also not found to be altered by presence of siRNAs (data not shown).

\section{Time course of skin reinnervation is unaffected by GFR $\alpha 3$ knockdown}

The time course of reinnervation of the hairy hindpaw skin by the axotomized and regenerating saphenous axons was determined by immunolabeling the skin with pan-axonal marker PGP9.5 (Fig. 3). We have previously shown that axotomy of the saphenous nerve causes complete denervation of the hairy hindpaw skin at $7 \mathrm{~d}$ after injury and that by $28 \mathrm{~d}$, both the epidermis and dermis show extensive reinnervation (Jankowski et al., 2009a). We verified these results in the current study. Four weeks after saphenous nerve axotomy, both the epidermis and dermis were heavily reinnervated by putative regenerated afferent fibers (Fig. $3 B$ ) and the extent of reinnervation appeared to be similar to that of uninjured control mice at this time point (Fig. $3 A$ ). The reinnervation of the skin by axotomized saphenous axons did not appear to be affected by injection of either PenCON siRNAs (Fig. $3 C$ ) or Pen $\alpha 3$ siRNAs (Fig. 3D). Similar reinnervation patterns were detected under all three experimental conditions at the 10-12 week time point (Fig. $3 F-H)$. We did not observe any obvious qualitative differences between proximal and distal portions of the cutaneous target at any of the time points or conditions tested (data not shown). It should be noted that using this histochemical approach, we are unable to determine the difference between regenerated fibers and possible collateral sprouts of intact fibers. To minimize this possibility, we have sampled areas of skin well within the borders of the saphenous nerve innervation field (Fig. 3E). Regardless, our subsequent recording experiments verified that ample reinnervation by regenerated sa- phenous nerve fibers in all three conditions had occurred by the 4-6 week time point. These results then allowed us to use our ex vivo somatosensory system preparation (Lawson et al., 2008) after axotomy and regeneration of the saphenous nerve.

\section{Response properties of A- and C-fiber neurons after saphenous nerve regeneration}

A total of 315 primary cutaneous neurons were intracellularly recorded and physiologically characterized from 60 nerveinjured Swiss-Webster mice. Of these, 107 cells came from 9 mice at the $4-6$ week time point and 10 mice at the 10-12 week time point in animals that only received saphenous nerve cut. An additional 104 cells were derived from 6 mice at the 4-6 week time and 9 mice at the 10-12 week time point in animals that received nerve cut plus control, nontargeting (PenCON) siRNA injection. The final 104 cells came from 9 mice at the $4-6$ week time and 13 mice at the 10-12 week time point in animals that received nerve cut plus GFR $\alpha 3$-targeting (Pen $\alpha 3$ ) siRNA injection. The results from these three experimental groups were compared with each other and to previously published results from naive SW mice (Jankowski et al., 2009a). Neurons with a conduction velocity of $<1.2 \mathrm{~m} / \mathrm{s}$ were classified as C-fibers (Kress et al., 1992), and all others were classified as A-fibers. Conduction velocities between 1.2 and $10 \mathrm{~m} / \mathrm{s}$ were considered to be in the $A \delta$ range, and those $\geq 10 \mathrm{~m} / \mathrm{s}$ were classified as conducting in the $\mathrm{A} \beta$ range (Koltzenburg et al., 1997; McIlwrath et al., 2007). For the purposes of these experiments, we have focused our recordings and analyses specifically on the population of regenerated C-fibers. In addition, in all nerve regenerated preparations we encountered a number of cells that were driven by the electrical nerve stimulus, but were found to be both mechanically and thermally unresponsive; however, only cells that had a response to cutaneous stimulation (mechanical or thermal) were included in the analysis.

The C-fiber classes included the following: (1) CPMs, which responded to mechanical and heat stimuli and sometimes cool/ cold stimuli; (2) C-mechano (CMs), which responded only to mechanical deformation of the cell's RF; (3) C-mechano cool/ cold (CMCs), which responded to mechanical and cooling stimuli (but not heating); (4) CHs, which were mechanically insensitive but responded to heat stimuli; and (5) C-cooling/cold (CCs), which were mechanically insensitive but responded to lowering the skin temperature. Cold threshold in the CMCs was not found to be altered under either condition at either time point. Mechanical threshold was also unchanged under any condition in the CMCs (data not shown). Inhibition of GFR $\alpha 3$ appeared to alter the mechanical threshold of CM neurons compared to axotomy alone and PenCON siRNA injection plus axotomy; however, given the small numbers of cells recorded for this fiber type under the different experimental conditions, further statistical analysis was not feasible. Additional analysis of the $\mathrm{C}$-fiber responses focused on the remaining two types of cutaneous $\mathrm{C}$-fibers (CPMs and $\mathrm{CHs}$ ).

\section{Neurochemical identity of CPM and $\mathrm{CH}$ neurons after saphenous nerve regeneration}

A total of 62 cutaneous C-fibers were intracellularly labeled, recovered, and immunohistochemically characterized in nerveinjured mice from the three experimental conditions. We found that the distribution of histochemical phenotypes in these single characterized sensory neurons was very similar to that previously observed following regeneration (Jankowski et al., 2009a). Across all experimental groups, the majority of regenerated fibers were CPMs. Thirty-three of forty-one CPM fibers (80\%) bound IB4, 

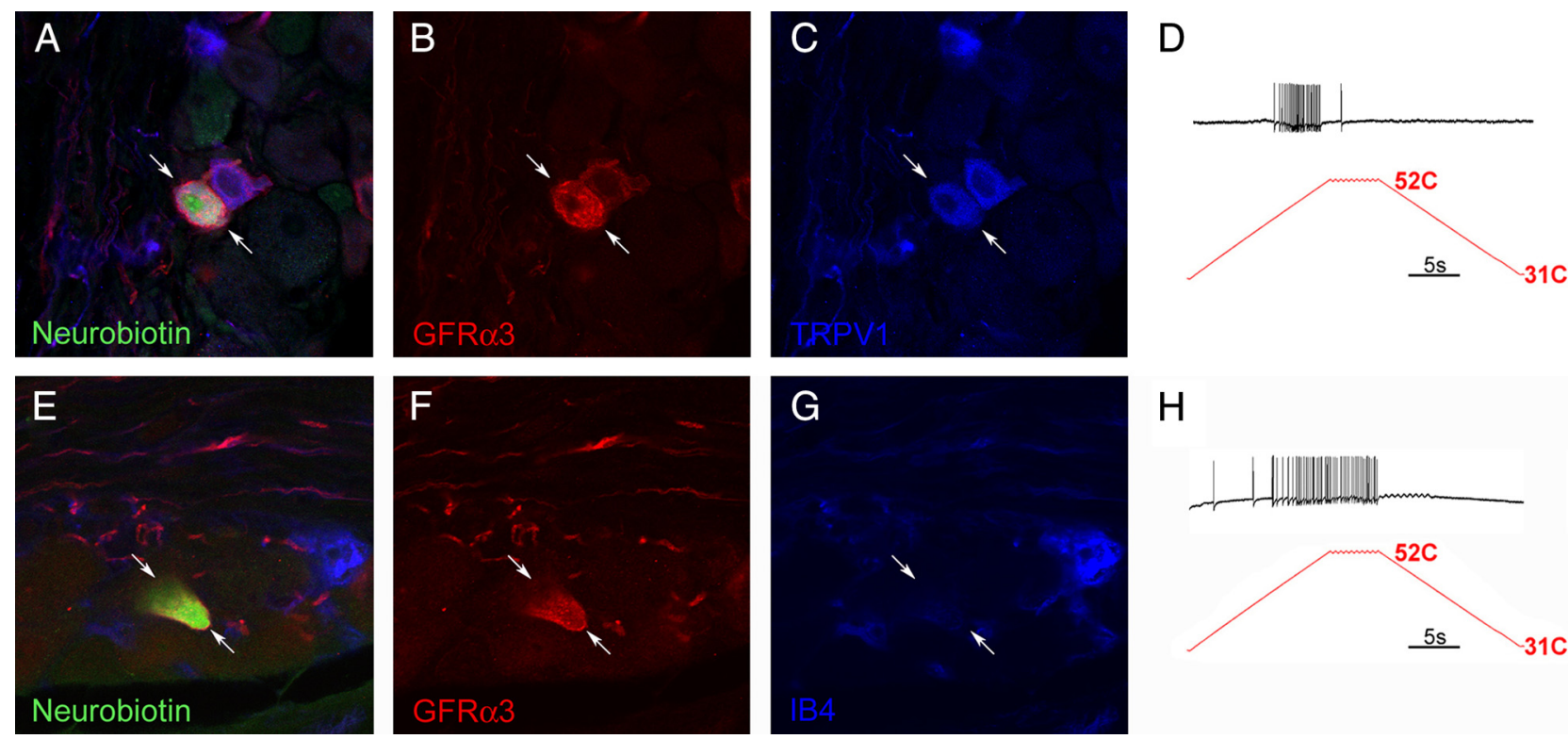

$\mathrm{H}$

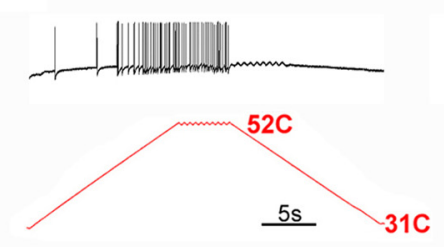

Figure 5. Characterization of the immunocytochemical and electrophysiological response properties of CHs in the L2/L3 DRGs using the saphenous nerve ex vivo preparation. Examples of cutaneous sensory neurons intracellularly labeled with Neurobiotin $(\boldsymbol{A}, \boldsymbol{E}$; arrows) were found to be immunopositive for GFR $\alpha 3(\boldsymbol{B}, \boldsymbol{F}$; arrows) and positive for TRPV1 ( $\boldsymbol{C}$, but these cells were never found to be positive for IB4 ( $\boldsymbol{G}$; arrows). These cells did not respond to mechanical stimulation, but did respond to heat stimulation $(\boldsymbol{D}, \boldsymbol{H})$, classifying them as $\mathrm{CH}$.

whereas 3 of $17(18 \%)$ stained positively for TRPV1 after axotomy and regeneration. Interestingly, in those mice receiving GFR $\alpha 3$ targeting siRNA injections, none of the 7 CPM neurons stained positively for TRPV1.

In naive wild-type mice, virtually all GFR $\alpha 3$-positive cells also stain positively for TRPV1 (Elitt et al., 2006). Therefore, naive cutaneous CPM fibers would be GFR $\alpha 3$ immunonegative; however, as for TRPV1, we found that some of the regenerated CPM fibers (7 of 46) stained positively for GFR $\alpha 3$ after injury (Fig. 4, Table 1). To determine whether these GFR $\alpha 3$ positive fibers were the population of TRPV1 and GFR $\alpha 3$-positive $\mathrm{CH}$ fibers that were possibly gaining mechanical sensitivity, 12 regenerated CPM fibers were processed for both GFR $\alpha 3$ and TRPV1 immunoreactivity. Three of these cells were double labeled for both markers; the remaining cells were immunonegative for both GFR $\alpha 3$ and TRPV1. It is again interesting to note that in those cases from mice injected with GFR $\alpha 3$ targeting siRNAs, none of the four CPM fibers processed for these two markers were TRPV1 or GFR $\alpha 3$ positive. In addition, 34 cells were processed for both IB4 binding and GFR $\alpha 3$ immunoreactivity. Only one cell was found to colabel for both of these markers (Table 1). These findings suggest that the increase in the numbers of GFR $\alpha 3$-positive cells following axotomy (Bennett et al., 2000) is the result of de novo or increased expression in a population of fibers that are TRPV1 negative and lack IB4 binding. This would most likely be the population of CPM fibers that are peptidergic, but lack TRPV1 (Lawson et al., 2008; Jankowski et al., 2009a).

For the $\mathrm{CH}$ fibers following regeneration, all five were immunopositive for TRPV1, consistent with our previous reports (Fig.

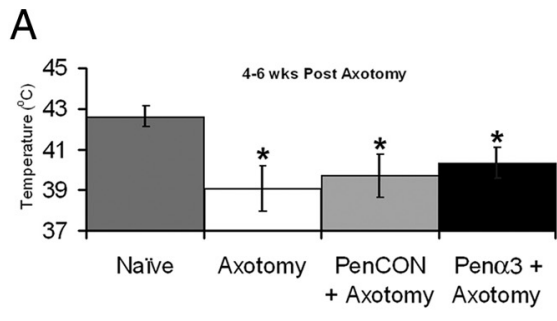

B
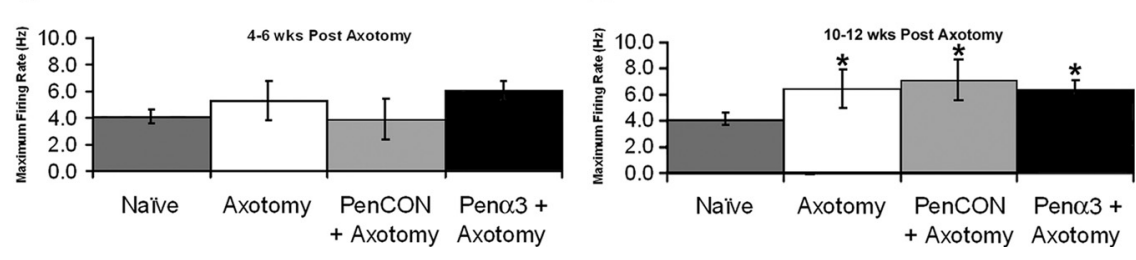

Figure 6. Electrophysiological response properties of polymodal C-fiber neurons before and after axotomy of the saphenous nerve in the skin-nerve DRG -spinal cord ex vivo preparation. CPMs showed a significant reduction in thermal threshold at 4-6 weeks and $10-12$ weeks after regeneration ( $n=18,4-6$ weeks and $n=23,10-12$ weeks) with or without injection of either PenCON ( $n=17,4-6$ weeks and $n=21,10-12$ weeks) siRNAs or Pen $\alpha 3$ ( $n=23,4-6$ weeks and $n=18,10-12$ weeks) siRNAs $(\boldsymbol{A}, \boldsymbol{B})$ compared to naive $(n=60)$ mice. ${ }^{*} p<0.003$. The maximum number of spikes per second in CPM neurons during heat ramp was not affected by axotomy under any condition (naive: $4.1 \pm 0.5 \mathrm{~Hz}$, axotomy: $5.3 \pm 0.9 \mathrm{~Hz}$, PenCON + axotomy: $3.9 \pm 1 \mathrm{~Hz}$, Pen $\alpha 3+$ axotomy: $6.1 \pm 1.6 \mathrm{~Hz}$ ) at $4-6$ weeks $(C)$ but was significantly increased in all conditions (naive: $4.1 \pm 0.5$ $\mathrm{Hz}$, axotomy: $6.4 \pm 1.4 \mathrm{~Hz}$, PenCON+axotomy: $7.1 \pm 1.6$, Pen $\alpha 3+$ axotomy: $6.4 \pm 0.7 \mathrm{~Hz}$ ) by $10-12$ weeks after injury compared to naive animals $(\boldsymbol{D}) .{ }^{*} p<0.04$.

5, Table 1) (Jankowski et al., 2009a). In addition, all eight $\mathrm{CH}$ neurons tested were also found to be immunoreactive for GFR $\alpha 3$, and all five $\mathrm{CH}$ neurons tested were found to colabel for TRPV1 and GFR $\alpha 3$. Finally, none of the three $\mathrm{CH}$ neurons were found to bind IB4 (Table 1) following regeneration.

To determine the extent of GFR $\alpha 3$ immunoreactivity after regeneration with or without inhibition of GFR $\alpha 3$, we counted the average number of GFR $\alpha 3$ neurons in the DRGs after axotomy. The average numbers of GFR $\alpha 3$-positive cells found per field of view was not statistically different for the 4-6 week and 10-12 week time points under each condition; therefore, the 


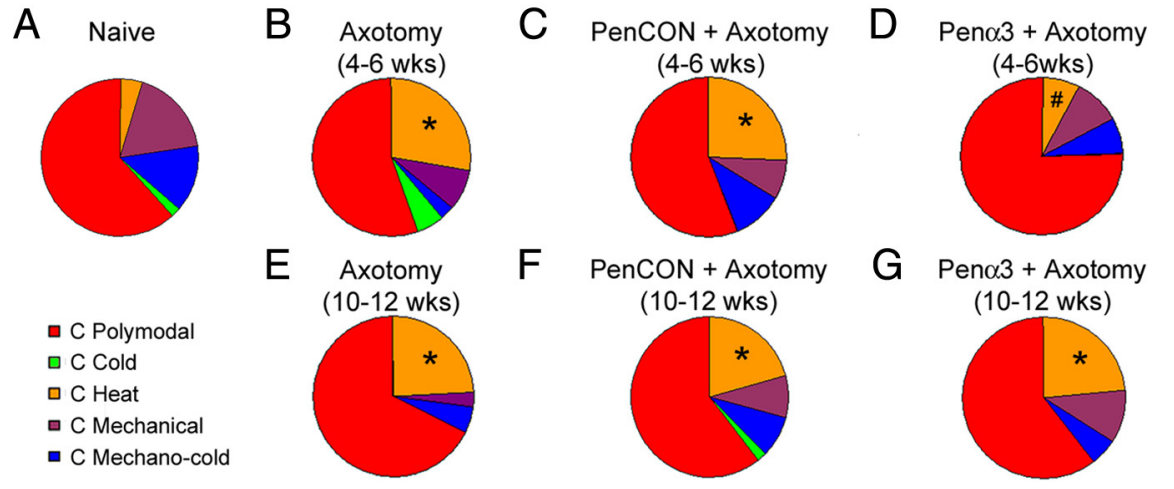

Figure 7. Phenotypes of C-fibers before and after saphenous nerve transection as characterized by ex vivo recording. $\boldsymbol{A}$, Most of the C-fibers are CPMs under normal conditions. The remaining C-fibers are approximately of equal representation comprised of CMCs, CMs, CCs, and CHs. B, Regenerated C-fibers display a shift in the distribution of fiber types in that there is a significant increase (naive $=5 \%$; axotomy $=28 \%$ ) in the percentage of $\mathrm{CHs}$ at $4-6$ weeks after injury. $\boldsymbol{C}$, These findings are also observed after injection of PenCON siRNAs (26\%) and axotomy at $4-6$ weeks after injury. $\boldsymbol{D}$, The axotomy-induced recruitment of $C H$ neurons is blocked by injection of Pen $\alpha 3$ siRNAs (7\%) at this time point. $\boldsymbol{E}, \boldsymbol{F}$, A significant increase in CH neuron prevalence is still detected $10-12$ weeks after regeneration of saphenous afferents after axotomy alone (24\%) and PenCON siRNA injection plus axotomy (21\%). G, Surprisingly, CH neuron recruitment was detected after Pen $\alpha 3$ siRNA injection plus axotomy (24\%) at this late time point. ${ }^{*} p$ values $<0.001$; ${ }^{\#} p<0.6$. Increases in $\mathrm{CH}$ neuron prevalence corresponded to a significant decrease in sum of CM and CMCs after axotomy and PenCON + axotomy $(p<0.02)$. There was not a significant decrease in CMs and CMCs after Pen $\alpha 3+$ axotomy $(p<0.07)$

results were combined for ease of presentation. In uninjured mice, the average number of GFR $\alpha 3$ cells per field of view was $30.3 \pm 2.2$ in the L3 DRGs. After axotomy alone, there was a significant increase in GFR $\alpha 3$ labeling relative to naive mice as the average number of cells found rose to $37.5 \pm 1.5(p<0.01)$. Similar results were observed in mice that received PenCON siRNA injection plus axotomy $(35.8 \pm 1.5 ; p<0.01)$. Pen $\alpha 3$ siRNA injection blocked the increase in GFR $\alpha 3$ labeling following axotomy compared to uninjured mice, as only $32.9 \pm 1.2$ neurons per field were immunopositive for GFR $\alpha 3(p<0.07)$. These findings are consistent with the results from real-time PCR and Western blot analysis.

\section{GFR $\alpha 3$ knockdown does not affect response properties of regenerated CPM neurons}

Shortly after functional reinnervation of the cutaneous target (4-6 weeks), CPM thermal thresholds were significantly reduced to $39.1 \pm 1.1^{\circ} \mathrm{C}(p=0.003)$ compared to previous naive mouse data $\left(42.6 \pm 0.5^{\circ} \mathrm{C}\right)$. Similar reduction in threshold was detected in mice that received PenCON siRNA injection (39.7 \pm $\left.1.1^{\circ} \mathrm{C}\right)$ or Pen $\alpha 3$ siRNA injections $\left(40.4 \pm 0.8^{\circ} \mathrm{C}\right)$ plus axotomy (Fig. $6 A$ ). Mean peak firing rate during the heat ramp was unaffected, however, under any condition at the $4-6$ week time point (Fig. 6C). At 10-12 weeks after saphenous nerve axotomy and regeneration, CPMs still showed a significant decrease in thermal threshold $\left(39.3 \pm 0.9^{\circ} \mathrm{C} ; p=0.0002\right)$. Injection of PenCON siRNAs $\left(40.0 \pm 0.7^{\circ} \mathrm{C}\right)$ or Pen $\alpha 3$ siRNAs $\left(39.0 \pm 0.8^{\circ} \mathrm{C}\right)$ also did not affect the axotomy-induced decrease in heat threshold (Fig. $6 \mathrm{~B}$ ). However, by $10-12$ weeks after axotomy, CPM neurons in mice from all three experimental conditions displayed an increase in mean peak firing rate during the heat stimulation (Fig. 6D) (naive: $4.1 \pm 0.5 \mathrm{~Hz}$; axotomy: $6.4 \pm 1.4 \mathrm{~Hz}$; PenCON + axotomy: $7.1 \pm 1.6 \mathrm{~Hz}$; Pen $\alpha 3+$ axotomy: $6.4 \pm 0.7 \mathrm{~Hz} ; p<$ 0.04). CPM mechanical threshold was not altered at any time point under any condition (data not shown). In summary, GFR $\alpha 3$-targeted siRNA injections had no effects on regenerated CPM fibers.

\section{GFR $\alpha 3$ knockdown blocks the recruitment of functional $\mathrm{CH}$ fibers following regeneration}

$\mathrm{CH}$ fibers showed no significant changes in thermal threshold or firing rate at any time points tested after axotomy under any condition (thresholds-naive: $41.0 \pm$ $1.6^{\circ} \mathrm{C}$; combined time points: axotomy: $44.0 \pm 1.3^{\circ} \mathrm{C}$; PenCON + axotomy: $42.9 \pm 1.4^{\circ} \mathrm{C}$; Pen $\alpha 3+$ axotomy: $40.8 \pm$ $1.7^{\circ} \mathrm{C}$; mean peak firing rates-naive: $3.0 \pm 1.2 \mathrm{~Hz}$; combined time points: axotomy: $6.1 \pm 1.5 \mathrm{~Hz}$; PenCON + axotomy: $7.3 \pm 2.4 \mathrm{~Hz}$; Pen $\alpha 3+$ axotomy: $9.4 \pm 3.9$ $\mathrm{Hz} ; p<0.3)$. However, the prevalence of $\mathrm{CH}$ fibers significantly increased after regeneration (Fig. 7). At 4-6 weeks following nerve cut, $28 \%$ of all recorded C-fibers were found to be mechanically insensitive $\mathrm{CH}$ neurons (Fig. 7B) $(p<0.001)$ compared to naive mice (5\%) (Fig. $7 A$ ). A similar increase in $\mathrm{CH}$ neuron prevalence was detected in mice that received PenCON siRNA injection plus axotomy (26\%) (Fig. 7C) $(p<0.001)$; however, at this time point, mice that received $\operatorname{Pen} \alpha 3$ siRNAs plus axotomy did not show $\mathrm{CH}$ fiber recruitment $(7 \%)$ (Fig. 7D) $(p=0.5)$.

By 10-12 weeks after nerve cut, this percentage was still elevated after axotomy alone $(24 \%)$ (Fig. $7 E)(p<0.001)$ and after PenCON siRNA injection plus axotomy (21\%) (Fig. $7 F)(p<$ $0.001)$. Recovery of $\mathrm{CH}$ neuron recruitment was also detected in the Pen $\alpha 3$ siRNA-injected mice by this time point (24\%) (Fig. $7 G)(p<0.001)$. The increase in $\mathrm{CH}$ fibers was coupled with a significant decrease in the combined numbers of CMC and CM fibers after axotomy and PenCON siRNA injection plus axotomy $(p<0.02)$, suggesting that the increase of $\mathrm{CH}$ fibers was due to recruitment from these populations. There was not a significant decrease in the sum of CMs and CMCs after Pen $\alpha 3$ siRNA injection plus axotomy, although there was a trend toward statistical significance $(p<0.07)$.

\section{GFR $\alpha 3$ knockdown during regeneration alters the expression of TRPV1 in DRG neurons}

In our previous study, we noted that the increase in $\mathrm{CH}$ neurons following reinnervation was correlated with an increased expression of TRPV 1 in the DRGs $28 \mathrm{~d}$ following axotomy, suggesting a potential role for TRPV1 in the recruitment of $\mathrm{CH}$ neurons (Jankowski et al., 2009a). To further investigate the potential role of TRPV1 in the artemin/GFR $\alpha 3$-mediated $\mathrm{CH}$ neuron recruitment, we first performed Western blot analysis on the hairy hindpaw skin for artemin 28 and $70 \mathrm{~d}$ following saphenous nerve transection. At $28 \mathrm{~d}$ following axotomy when most fibers had reinnervated the skin, there was a significant increase in the levels of artemin protein $(145 \pm 67 \%)$, and these levels were found to remain elevated $(120 \pm 70 \%)$ at $70 \mathrm{~d}$ after saphenous nerve axotomy (Fig. $8 A, B)$ ( $p$ values $<0.05$ ), suggesting that the regenerated fibers had access to enhanced target-derived artemin for 2 months after reinnervation of the skin. This sustained increase in cutaneous artemin is correlated with the recovery of the increased $\mathrm{CH}$ prevalence normally seen at $10-12$ weeks following axotomy.

We assumed that the increase in target-derived artemin would increase artemin signaling in regenerating neurons as long as 

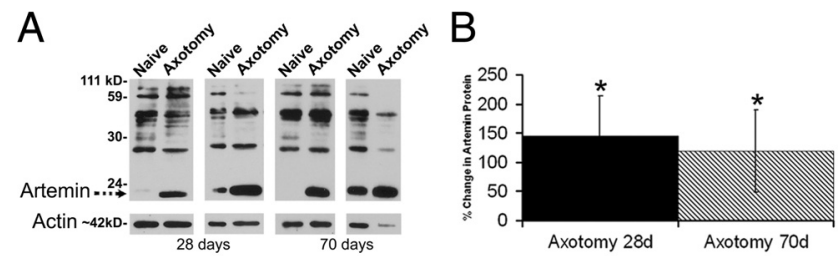

C

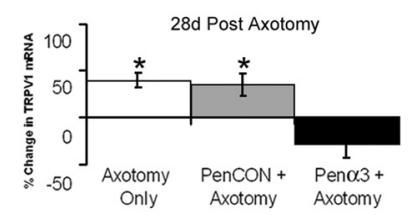

D

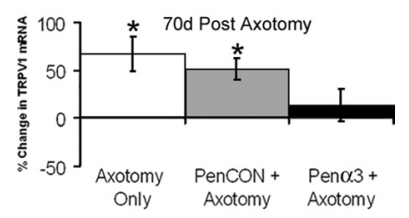

$\mathrm{E}$

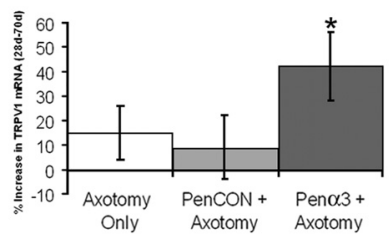

$\mathrm{F}$

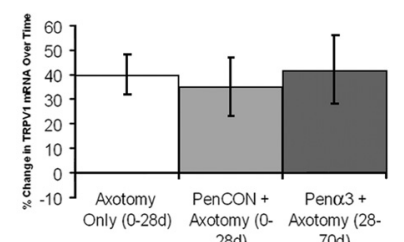

28d)

Figure 8. Expression of artemin in hairy hindpaw skin and TRPV1 in L2/L3 DRGs at 4 and 10 weeks after saphenous nerve axotomy with or without injection of PenCON or Pen $\alpha 3$ siRNAs. Two representative Western blots are shown for artemin protein normalized to actin in the hairy hindpaw skin after axotomy and regeneration at 28 and $70 \mathrm{~d}$. The antibody used produces multiple bands with Western blotting, but the mouse artemin protein (dashed arrow) is clearly detected at the appropriate size around $24 \mathrm{kDa}(\boldsymbol{A})$. Western blot analysis of hairy hindpaw skin showed that there was a significant increase in the levels of artemin protein immediately after reinnervation of regenerating saphenous afferents at $28 \mathrm{~d}(145 \pm 67 \%)$, and this level was maintained until at least $70 \mathrm{~d}(120 \pm 70 \%)(\boldsymbol{B})$. TRPV1 mRNA is significantly increased in the L2/L3 DRGs $28 \mathrm{~d}$ after axotomy alone ( $40 \pm 8 \%$ ) and with injection of PenCON siRNAs ( $35 \pm$ 12\%). Inhibition of GFR $\alpha 3$ expression with injection of Pen $\alpha 3$ siRNAs plus axotomy ( $-28 \pm$ 16\%) prevented the injury-induced expression of TRPV1 at $28 \mathrm{~d}$ (C). Surprisingly, the increase in TRPV1 expression at $70 \mathrm{~d}$ after axotomy $(67 \pm 18 \%)$ or after PenCON siRNA injection and axotomy (51 $\pm 11 \%$ ) was maintained out to $70 \mathrm{~d}$, but mRNA levels did not rebound after Pen $\alpha 3$ injection and axotomy $(14 \pm 16 \%)$ compared to naive mice $(\boldsymbol{D})$. However, the percentage increase in TRPV1 mRNA from 28 to $70 \mathrm{~d}$ after axotomy alone (15 $\pm 11 \%$ ) or PenCON siRNA plus axotomy $(9 \pm 13 \%)$ was not significant, whereas the increase in TRPV1 mRNA was significantly increased after Pen $\alpha 3$ siRNA injection plus axotomy ( $42 \pm 14 \%$ ) between these time points $(\boldsymbol{E})$. The percentage increase in TRPV1 mRNA from 0 to $28 \mathrm{~d}$ after axotomy ( $40 \pm 8 \%$ ) or PenCON plus axotomy $(35 \pm 12 \%$ ) is similar to the increase in TRPV1 expression from 28 to $70 \mathrm{~d}$ (42 $\pm 14 \%$ ) after Pen $\alpha 3$ siRNA injection plus axotomy $(\boldsymbol{F}) .{ }^{*} p<0.05$.

GFR $\alpha 3$ levels were maintained at normal levels. To determine whether this putative increase in artemin signaling was correlated with changes in TRPV1 expression in the DRGs, we performed RT-PCR analysis on L2/L3 DRGs at 28 and $70 \mathrm{~d}$ after axotomy. At $28 \mathrm{~d}$, TRPV1 was found to be statistically increased in the DRGs (Fig. $8 C$ ) after axotomy alone $(40 \pm 8 \%)$ and after PenCON siRNA injection plus axotomy $(35 \pm 12 \%)$. However, Pen $\alpha 3$ injection plus axotomy $(-28 \pm 16 \%)$ completely inhibited the injury-induced increase in TRPV1 mRNA (Fig. 8C) at this time point. Thus, the changes in TRPV1 mRNA levels were directly correlated with the increased prevalence of $\mathrm{CH}$ neurons. At $70 \mathrm{~d}$ after axotomy, TRPV1 expression remained elevated in the DRGs after axotomy alone $(67 \pm 18 \%)$ and after PenCON siRNA injection plus axotomy ( $51 \pm 11 \%)$, while TRPV1 mRNA in mice with Pen $\alpha 3$ injection plus axotomy $(14 \pm 16 \%)$ remained at naive levels (Fig. $8 D$ ). This suggests that the recovery in the prevalence of $\mathrm{CH}$ fibers to axotomy alone levels out at 10 weeks following axotomy is not correlated with an increase in TRPV1 expression. However, a closer examination of the data revealed that there was a significant rebound in TRPV 1 expression between 28 and $70 \mathrm{~d}$ in mice receiving Pen $\alpha 3$ siRNA at the time of injury (Fig. $8 E$ ) $(p<0.05)$, which was similar to the changes in TRPV1 observed in control DRGs from 0 to $28 \mathrm{~d}$ (Fig. $8 \mathrm{~F}$ ).

\section{Discussion}

Specificity and duration of in vivo siRNA knockdown

We found that injection of Penetratin-1-modified, GFR $\alpha 3$ targeting siRNAs into the saphenous nerve could completely block the axotomy-induced increase in GFR $\alpha 3$ mRNA and protein in the DRG $7 \mathrm{~d}$ after injury. However, since the regenerating saphenous axons take several weeks to functionally reinnervate the skin (Jankowski et al., 2009a), it was important to also examine the long-term effects of targeted siRNA knockdown. We found that in untreated, regenerating mice, GFR $\alpha 3$ mRNA was elevated only at 1 week following axotomy; however, GFR $\alpha 3$ protein remained elevated for at least 4 weeks. Therefore, at the time axons are initially reinnervating the skin, GFR $\alpha 3$ protein is normally elevated significantly. This increase coupled with elevated cutaneous artemin should provide the potential for enhanced signaling in GFR $\alpha 3$-containing neurons. We also found that inhibition of GFR $\alpha 3$ mRNA could prevent this prolonged increase in GFR $\alpha 3$ protein in the DRGs, thus reducing possible enhanced signaling following reinnervation of the skin.

Off-target effects are always a concern when using siRNA techniques. Previously we demonstrated that these injections did not activate the interferon viral response pathway (Jankowski et al., 2009b) that has been shown to be associated with off-target effects of RNAi strategies (e.g., Alvarez et al., 2006). Here we have confirmed this by finding a lack of a change in IFN-type I after siRNA injection (data not shown).

The effects of targeting siRNA injections used here are apparently restricted to the population of cutaneous afferents that express GFR $\alpha 3$. For example, we have previously found that similar to GFR $\alpha 3$, axotomy of the saphenous nerve results in a significant increase in the expression of $\mathrm{P} 2 \mathrm{X} 3 \mathrm{mRNA}$ by 1 week following the lesion (Jankowski et al., 2009a). P2X3 is contained in the population of IB4-positive cells (Zwick et al., 2002) that we have determined to be nonpeptidergic CPM fibers (Lawson et al., 2008; Jankowski et al., 2009a). Neither injection of nontargeting siRNAs nor injection of GFR $\alpha 3$-targeting siRNAs altered the axotomy-induced expression of $\mathrm{P} 2 \mathrm{X} 3$, suggesting that any changes in mRNA due to the siRNAs were likely specific to GFR $\alpha 3$. GFR $\alpha 3$ knockdown also had no effect on the heat sensitization of this fiber type (CPMs) normally observed following regeneration (Jankowski et al., 2009a). In addition, GFR $\alpha 3$ targeting siRNAs had no effect on other genes of this receptor family, such as GFR $\alpha 1$ or GFR $\alpha 2$, nor did they have an effect on ret expression. Together these results strongly suggest that effects of the targeted siRNA injection are specific.

It should be noted that like other neurotrophic factors (e.g., NGF, BDNF, NT4) (Johnson et al., 1988; Funakoshi et al., 1993), artemin expression is increased, presumably in Schwann cells, in the distal nerve segment following nerve transection (Baloh et al., 1998). It has also been suggested that enhanced artemin levels can regulate axon regeneration (Wang et al., 2008). Thus, it is possible that following injection of GFR $\alpha 3$-targeting siRNAs, Schwann cells in the vicinity of the injection could also be transfected and potential knockdown in these cells could affect the ability of GFR $\alpha 3$-positive axotomized fibers to regenerate at normal rates. However this enhanced regeneration is thought to be indirect and generalized to all axon types, as the effects are seen in other fibers that do not express GFR $\alpha 3$ (e.g., motor axons) (Widenfalk et al., 2009). Together with our findings that the 
siRNA injections do not appear to affect the regeneration rate of the axotomized fibers, this suggests that the inhibition of $\mathrm{CH}$ fiber recruitment is not due to specific regeneration effects on this population of fibers, although we cannot completely rule this out.

\section{GFR $\alpha 3$ knockdown in vivo inhibits increased TRPV1 expression and the recruitment of $\mathrm{CH}$ neurons after regeneration}

In agreement with our previous study, we found that following regeneration, there is a significant increase in the numbers of functional CH fibers (Jankowski et al., 2009a). Control siRNA injections had no effect on this increase, while injection of GFR $\alpha 3$-targeting siRNAs completely blocked this increase at 4-6 weeks. Importantly, this injection had no effect on the population of largely nonpeptidergic, TRPV1-negative, GFR $\alpha 3$-negative, CPM fibers as they exhibited the same decrease in heat threshold across the three experimental groups. In addition, this lack of $\mathrm{CH}$ fiber recruitment was correlated with inhibition of the increase in TRPV1 expression normally observed following nerve regeneration, which is consistent with our hypothesis that this change in function requires an increase in TRPV1.

To examine the long-term effects of these injections, we also examined the same experimental groups at longer intervals (10-12 weeks) following axotomy. We found at this time point that there was a recovery in the recruitment of $\mathrm{CH}$ fibers. This is not surprising given the relatively transient effects of siRNAs, and this also suggests that the cells are not permanently altered by presence of siRNAs. Although there was no increase in GFR $\alpha 3$ at this longer time point, it is quite possible that the enhanced levels of artemin present in the skin over this period of time could potentially enhance GFR $\alpha 3$-mediated signaling in this population of fibers.

Conversely, we did not see a recovery in TRPV1 expression to levels observed in the control groups at this time point. This would suggest that an absolute level of TRPV1 may not be essential for recovery in $\mathrm{CH}$ recruitment. This also suggests the possibility that other changes downstream of GFR $\alpha 3 /$ Ret signaling may be important for this process. However, there was a significant rebound in TRPV1 in the GFR $\alpha 3$-targeting siRNA-injected group over the later time points $(28-70 \mathrm{~d})$. Thus the dynamic change in expression could be sufficient for the recovery of $\mathrm{CH}$ fiber recruitment, but this will need to be directly tested in the future.

\section{Effects of siRNA knockdown on other changes in sensory neuron phenotypes after regeneration}

Nerve transection results in abundant plasticity in the expression of many neurochemical markers in sensory neurons. For example, CGRP expression and IB4 binding decreases, while GFR $\alpha 3$ and TRPV1 expression increases (Mulder et al., 1997; Bennett et al., 2000, 1998; Shadiack et al., 2001; Jankowski et al., 2009a). In some cases, these changes are reflected in a decrease or increase in the numbers of positively stained cells in the DRG as the numbers of cells binding IB4 and those staining positively for CGRP are reduced for a few weeks following injury. Conversely the increase in GFR $\alpha 3$ expression results in a significant increase in the numbers of positive cells, suggesting de novo expression. Whereas the numbers of IB4-binding (Jankowski et al., 2009a) and CGRPpositive cells are enhanced or recover following successful regeneration (McMahon and Gibson, 1987; McMahon et al., 1989), we have found that GFR $\alpha 3$ numbers remain elevated. However, siRNA knockdown of GFR $\alpha 3$ blocks this apparent increase and potential de novo expression, possibly contributing to the observed changes in function.

Analysis of the immunolabeling of characterized fibers also suggests specific effects of the GFR $\alpha 3$-targeting siRNAs. For example, we have previously shown that following nerve regeneration that some (16\%) TRPV1-positive $\mathrm{CH}$ fibers apparently gain mechanical sensitivity (Jankowski et al., 2009a). This apparent phenotypic switch produces CPM fibers that are TRPV1 positive, something that is never seen in naive mice (Woodbury et al., 2004; Lawson et al., 2008). This finding is confirmed in the present study such that following axotomy alone and axotomy plus control siRNA injections, we found 3 of 10 regenerated CPMs stained positively for TRPV1. However, in mice that received the GFR $\alpha 3$-targeting siRNA injections, none of the 7 regenerated CPMs stained positively for TRPV1. This suggests the possibility that the enhanced artemin/GFR $\alpha 3$ levels also play an essential role in acquisition of mechanical sensitivity in the $\mathrm{CH}$ population of cutaneous fibers.

\section{Clinical relevance}

We have recently reported that there are apparent similarities between the $\mathrm{CH}$ fibers found in mouse (Lawson et al., 2008) and nonhuman primates (Baumann et al., 1991) and the mechanically insensitive (MIA) C-fibers found in humans (Schmidt et al., 1995). In addition, changes observed in murine $\mathrm{CH}$ fibers following nerve injury are similar to those observed with human MIA fibers in patients suffering with chronic pain conditions (Jankowski et al., 2009a).

The data presented here suggests that some silent nociceptors are activated after injury and become responsive to heat, that some $\mathrm{CH}$ neurons gain mechanical sensitivity, and that this may be regulated by enhanced target-derived artemin and DRG GFR $\alpha 3$ levels. It is known that in patients with erythromelalgia, afferents with the biophysical properties of mechanically insensitive fibers (MIA) appeared to gain mechanical sensitivity (Ørstavik et al., 2003). Together these findings suggest a potential pronociceptive role for altered neurotrophic factor signaling on primary afferent sensitization in neuropathic pain states. Such a pronociceptive role for target-derived artemin is consistent with the findings of Malin et al. (2006), where cutaneous injection of artemin resulted in heat hyperalgesia.

However other studies have suggested an antinociceptive role of artemin. Gardell et al. (2003) had found that systemic delivery of artemin reduces the injury-induced decrease in paw withdrawal threshold to both mechanical and thermal stimulation (but also see Bolon et al., 2004). This suggests that target-derived and systemic artemin may play different roles in nociceptive processing, and additional future studies involving delivery of artemin in humans would facilitate our ability to determine the benefits of artemin in relieving chronic pain.

\section{References}

Albers KM, Woodbury CJ, Ritter AM, Davis BM, Koerber HR (2006) Glial cell-line-derived neurotrophic factor expression in skin alters the mechanical sensitivity of cutaneous nociceptors. J Neurosci 26:2981-2990.

Alvarez VA, Ridenour DA, Sabatini BL (2006) Retraction of synapses and dendritic spines induced by off-target effects of RNA interference. J Neurosci 26:7820-7825.

Amir R, Michaelis M, Devor M (1999) Membrane potential oscillations in dorsal root ganglion neurons: role in normal electrogenesis and neuropathic pain. J Neurosci 19:8589-8596.

Baloh RH, Gorodinsky A, Golden JP, Tansey MG, Keck CL, Popescu NC, Johnson EM Jr, Milbrandt J (1998) GFRalpha3 is an orphan member of the GDNF/neurturin/persephin receptor family. Proc Natl Acad Sci U S A 95:5801-5806. 
Baumann TK, Simone DA, Shain CN, LaMotte RH (1991) Neurogenic hyperalgesia: the search for the primary cutaneous afferent fibers that contribute to capsaicin-induced pain and hyperalgesia. J Neurophysiol 66:212-227.

Bennett DL, Michael GJ, Ramachandran N, Munson JB, Averill S, Yan Q, McMahon SB, Priestley JV (1998) A distinct subgroup of small DRG cells express GDNF receptor components and GDNF is protective for these neurons after nerve injury. J Neurosci 18:3059-3072.

Bennett DL, Boucher TJ, Armanini MP, Poulsen KT, Michael GJ, Priestley JV, Phillips HS, McMahon SB, Shelton DL (2000) The glial cell line-derived neurotrophic factor family receptor components are differentially regulated within sensory neurons after nerve injury. J Neurosci 20:427-437.

Bennett DL, Boucher TJ, Michael GJ, Popat RJ, Malcangio M, Averill SA, Poulsen KT, Priestley JV, Shelton DL, McMahon SB (2006) Artemin has potent neurotrophic actions on injured C-fibres. J Peripher Nerv Syst 11:330-345.

Bolon B, Jing S, Asuncion F, Scully S, Pisegna M, Van GY, Hu Z, Yu YB, Min H, Wild K, Rosenfeld RD, Tarpley J, Carnahan J, Duryea D, Hill D, Kaufman S, Yan XQ, Juan T, Christensen K, McCabe J, et al. (2004) The candidate neuroprotective agent artemin induces autonomic neural dysplasia without preventing peripheral nerve dysfunction. Toxicol Pathol 32:275-294.

Campbell JN (2001) Nerve lesions and the generation of pain. Muscle Nerve 24:1261-1273.

Carmillo P, Dagø L, Day ES, Worley DS, Rossomando A, Walus L, Orozco O, Buckley C, Miller S, Tse A, Cate RL, Rosenblad C, Sah DW, Grønborg M, Whitty A (2005) Glial cell line-derived neurotrophic factor (GDNF) receptor alpha-1 (GFR alpha 1) is highly selective for GDNF versus artemin. Biochemistry 44:2545-2554.

Christianson JA, Mcllwrath SL, Koerber HR, Davis BM (2006) Transient receptor potential vanilloid 1 -immunopositive neurons in the mouse are more prevalent within colon afferents compared to skin and muscle afferents. Neuroscience 140:247-257.

Davidson TJ, Harel S, Arboleda VA, Prunell GF, Shelanski ML, Greene LA, Troy CM (2004) Highly efficient small interfering RNA delivery to primary mammalian neurons induces MicroRNA-like effects before mRNA degradation. J Neurosci 24:10040-10046.

Decosterd I, Ji RR, Abdi S, Tate S, Woolf CJ (2002) The pattern of expression of the voltage-gated sodium channels $\mathrm{Na}(\mathrm{v}) 1.8$ and $\mathrm{Na}(\mathrm{v}) 1.9$ does not change in uninjured primary sensory neurons in experimental neuropathic pain models. Pain 96:269-277.

Derossi D, Chassaing G, Prochiantz A (1998) Trojan peptides: the penetratin system for intracellular delivery. Trends Cell Biol 8:84-87.

Djouhri L, Koutsikou S, Fang X, McMullan S, Lawson SN (2006) Spontaneous pain, both neuropathic and inflammatory, is related to frequency of spontaneous firing in intact C-fiber nociceptors. J Neurosci 26:12811292.

Elitt CM, McIlwrath SL, Lawson JJ, Malin SA, Molliver DC, Cornuet PK, Koerber HR, Davis BM, Albers KM (2006) Artemin overexpression in skin enhances expression of TRPV1 and TRPA1 in cutaneous sensory neurons and leads to behavioral sensitivity to heat and cold. J Neurosci $26: 8578-8587$.

Funakoshi H, Frisén J, Barbany G, Timmusk T, Zachrisson O, Verge VM, Persson H (1993) Differential expression of mRNAs for neurotrophins and their receptors after axotomy of the sciatic nerve. J Cell Biol 123:455-465.

Gardell LR, Wang R, Ehrenfels C, Ossipov MH, Rossomando AJ, Miller S, Buckley C, Cai AK, Tse A, Foley SF, Gong B, Walus L, Carmillo P, Worley D, Huang C, Engber T, Pepinsky B, Cate RL, Vanderah TW, Lai J, Sah DW, Porreca F (2003) Multiple actions of systemic artemin in experimental neuropathy. Nat Med 9:1383-1389.

Jankowski MP, Cornuet PK, Mcllwrath S, Koerber HR, Albers KM (2006) SRY-box containing gene 11 (Sox11) transcription factor is required for neuron survival and neurite growth. Neuroscience 143:501-514.

Jankowski MP, Lawson JJ, McIlwrath SL, Rau KK, Anderson CE, Albers KM, Koerber HR (2009a) Sensitization of cutaneous nociceptors after nerve transection and regeneration: possible role of target-derived neurotrophic factor signaling. J Neurosci 29:1636-1647.

Jankowski MP, Mcllwrath SL, Jing X, Cornuet PK, Salerno KM, Koerber HR, Albers KM (2009b) Sox11 transcription factor modulates peripheral nerve regeneration in adult mice. Brain Res 1256:43-54.

Johnson EM Jr, Taniuchi M, DiStefano PS (1988) Expression and possible function of nerve growth factor receptors on Schwann cells. Trends Neurosci 11:299-304.

Kajander KC, Bennett GJ (1992) Onset of a painful peripheral neuropathy in rat: a partial and differential deafferentation and spontaneous discharge in A beta and A delta primary afferent neurons. J Neurophysiol 68:734-744.

Koerber HR, Woodbury CJ (2002) Comprehensive phenotyping of sensory neurons using an ex vivo somatosensory system. Physiol Behav 77: 589-594.

Koerber HR, Mirnics K, Brown PB, Mendell LM (1994) Central sprouting and functional plasticity of regenerated primary afferents. J Neurosci 14:3655-3671.

Koerber HR, Mirnics K, Kavookjian AM, Light AR (1999) Ultrastructural analysis of ectopic synaptic boutons arising from peripherally regenerated primary afferent fibers. J Neurophysiol 81:1636-1644.

Koltzenburg M, Stucky CL, Lewin GR (1997) Receptive properties of mouse sensory neurons innervating hairy skin. J Neurophysiol 78:1841-1850.

Kress M, Koltzenburg M, Reeh PW, Handwerker HO (1992) Responsiveness and functional attributes of electrically localized terminals of cutaneous C-fibers in vivo and in vitro. J Neurophysiol 68:581-595.

Küry P, Stoll G, Müller HW (2001) Molecular mechanisms of cellular interactions in peripheral nerve regeneration. Curr Opin Neurol 14:635-639.

Lawson JJ, Mcllwrath SL, Woodbury CJ, Davis BM, Koerber HR (2008) TRPV1 unlike TRPV2 is restricted to a subset of mechanically insensitive cutaneous nociceptors responding to heat. J Pain 9:298-308.

Lundborg G, Dahlin L, Danielsen N, Zhao Q (1994) Trophism, tropism, and specificity in nerve regeneration. J Reconstr Microsurg 10:345-354.

Malin SA, Molliver DC, Koerber HR, Cornuet P, Frye R, Albers KM, Davis BM (2006) Glial cell line-derived neurotrophic factor family members sensitize nociceptors in vitro and produce thermal hyperalgesia in vivo. J Neurosci 26:8588-8599.

Mcllwrath SL, Lawson JJ, Anderson CE, Albers KM, Koerber HR (2007) Overexpression of neurotrophin-3 enhances the mechanical response properties of slowly adapting type 1 afferents and myelinated nociceptors. Eur J Neurosci 26:1801-1812.

McMahon SB, Gibson S (1987) Peptide expression is altered when afferent nerves reinnervate inappropriate tissue. Neurosci Lett 73:9-15.

McMahon SB, Lewin GR, Anand P, Ghatei MA, Bloom SR (1989) Quantitative analysis of peptide levels and neurogenic extravasation following regeneration of afferents to appropriate and inappropriate targets. Neuroscience 33:67-73.

Mulder H, Zhang Y, Danielsen N, Sundler F (1997) Islet amyloid polypeptide and calcitonin gene-related peptide expression are down-regulated in dorsal root ganglia upon sciatic nerve transection. Brain Res Mol Brain Res 47:322-330.

Oaklander AL, Brown JM (2004) Unilateral nerve injury produces bilateral loss of distal innervation. Ann Neurol 55:639-644.

Obata K, Yamanaka H, Fukuoka T, Yi D, Tokunaga A, Hashimoto N, Yoshikawa H, Noguchi K (2003) Contribution of injured and uninjured dorsal root ganglion neurons to pain behavior and the changes in gene expression following chronic constriction injury of the sciatic nerve in rats. Pain 101:65-77.

Orozco OE, Walus L, Sah DW, Pepinsky RB, Sanicola M (2001) GFRalpha3 is expressed predominantly in nociceptive sensory neurons. Eur J Neurosci 13:2177-2182.

Ørstavik K, Weidner C, Schmidt R, Schmelz M, Hilliges M, Jørum E, Handwerker H, Torebjörk E (2003) Pathological C-fibres in patients with a chronic painful condition. Brain 126:567-578.

Priestley JV, Michael GJ, Averill S, Liu M, Willmott N (2002) Regulation of nociceptive neurons by nerve growth factor and glial cell line derived neurotrophic factor. Can J Physiol Pharmacol 80:495-505.

Ruocco I, Cuello AC, Ribeiro-Da-Silva A (2000) Peripheral nerve injury leads to the establishment of a novel pattern of sympathetic fibre innervation in the rat skin. J Comp Neurol 422:287-296.

Sariola H, Saarma M (2003) Novel functions and signalling pathways for GDNF. J Cell Sci 116:3855-3862.

Schmidt R, Schmelz M, Forster C, Ringkamp M, Torebjörk E, Handwerker H (1995) Novel classes of responsive and unresponsive C nociceptors in human skin. J Neurosci 15:333-341.

Shadiack AM, Sun Y, Zigmond RE (2001) Nerve growth factor antiserum induces axotomy-like changes in neuropeptide expression in intact sympathetic and sensory neurons. J Neurosci 21:363-371. 
Smith DS, Skene JH (1997) A transcription-dependent switch controls competence of adult neurons for distinct modes of axon growth. J Neurosci 17:646-658.

Taniuchi M, Clark HB, Johnson EM Jr (1986) Induction of nerve growth factor receptor in Schwann cells after axotomy. Proc Natl Acad Sci U S A 83:4094-4098.

Terenghi G (1995) Peripheral nerve injury and regeneration. Histol Histopathol 10:709-718.

Tsujino H, Kondo E, Fukuoka T, Dai Y, Tokunaga A, Miki K, Yonenobu K, Ochi T, Noguchi K (2000) Activating transcription factor 3 (ATF3) induction by axotomy in sensory and motoneurons: a novel neuronal marker of nerve injury. Mol Cell Neurosci 15:170-182.

Wall PD, Devor M (1983) Sensory afferent impulses originate from dorsal root ganglia as well as from the periphery in normal and nerve injured rats. Pain 17:321-339.

Wang R, Guo W, Ossipov MH, Vanderah TW, Porreca F, Lai J (2003) Glial cell line-derived neurotrophic factor normalizes neurochemical changes in injured dorsal root ganglion neurons and prevents the expression of experimental neuropathic pain. Neuroscience 121:815-824.

Wang R, King T, Ossipov MH, Rossomando AJ, Vanderah TW, Harvey P, Cariani P, Frank E, Sah DW, Porreca F (2008) Persistent restoration of sensory function by immediate or delayed systemic artemin after dorsal root injury. Nat Neurosci 11:488-496.
Waxman SG (1999) The molecular pathophysiology of pain: abnormal expression of sodium channel genes and its contributions to hyperexcitability of primary sensory neurons. Pain [Suppl 6]:S133-S140.

Widenfalk J, Wu W, Hao J, Person JK, Wiesenfeldt-Hallin Z, Risling M (2009) Treatment of transected peripheral nerves with artemin improved motor neuron regeneration, but did not reduce nerve injuryinduced pain behaviour. Scand J Plast Reconstr Surg Hand Surg 43:245-250.

Woodbury CJ, Ritter AM, Koerber HR (2001) Central anatomy of individual rapidly adapting low-threshold mechanoreceptors innervating the "hairy" skin of newborn mice: early maturation of hair follicle afferents. J Comp Neurol 436:304-323.

Woodbury CJ, Zwick M, Wang S, Lawson JJ, Caterina MJ, Koltzenburg M, Albers KM, Koerber HR, Davis BM (2004) Nociceptors lacking TRPV1 and TRPV2 have normal heat responses. J Neurosci 24:6410-6415.

Xie Y, Zhang J, Petersen M, LaMotte RH (1995) Functional changes in dorsal root ganglion cells after chronic nerve constriction in the rat. J Neurophysiol 73:1811-1820.

Zwick M, Davis BM, Woodbury CJ, Burkett JN, Koerber HR, Simpson JF, Albers KM (2002) Glial cell line-derived neurotrophic factor is a survival factor for isolectin B4-positive, but not vanilloid receptor 1-positive, neurons in the mouse. J Neurosci 22:4057-4065. 